\title{
Water Deficit Modulates the Response of Vitis vinifera to the Pierce's Disease Pathogen Xylella fastidiosa
}

\author{
Hong-Kyu Choi, ${ }^{1}$ Alberto landolino, ${ }^{2}$ Francisco Goes da Silva, ${ }^{2}$ and Douglas R. Cook ${ }^{2}$ \\ ${ }^{1}$ Department of Genetic Engineering, Dong-A University, Bussan 604-714, Republic of Korea; ${ }^{2}$ Department of Plant \\ Pathology, University of California, Davis 95616, U.S.A.
}

Submitted 19 September 2012. Accepted 7 February 2013.

Pierce's disease, caused by the bacterium Xylella fastidiosa, is one of the most devastating diseases of cultivated grape, currently restricted to the Americas. To test the long-standing hypothesis that Pierce's disease results from pathogeninduced drought stress, we used the Affymetrix Vitis GeneChip to compare the transcriptional response of Vitis vinifera to Xylella infection, water deficit, or a combination of the two stresses. The results reveal a redirection of gene transcription involving 822 genes with a minimum twofold change $(P<0.05)$, including the upregulation of transcripts for phenylpropanoid and flavonoid biosynthesis, pathogenesis-related proteins, abscisic acid- and jasmonic acidresponsive biosynthesis, and downregulation of transcripts related to photosynthesis, growth, and nutrition. Although the transcriptional response of plants to Xylella infection was largely distinct from the response of healthy plants to water stress, we find that 138 of the pathogen-induced genes exhibited a significantly stronger transcriptional response when plants were simultaneously exposed to infection and drought stress, suggesting a strong interaction between disease and water deficit. This interaction between drought stress and disease was mirrored in planta at the physiological level for aspects of water relations and photosynthesis and in terms of the severity of disease symptoms and the extent of pathogen colonization, providing a molecular correlate of the classical concept of the disease triangle in which environment impacts disease severity.

Xylella fastidiosa establishes intimate, lasting endophytic associations with plant hosts, where it is limited exclusively to xylem tissues (Chatterjee et al. 2008a; Hopkins 1989). Associations of individual bacterial strains are often observed in multiple plant species at the scale of local landscapes (Sherald and Kostka 1992), while a range of X. fastidiosa strains are documented inhabitants of numerous of individual species (Purcell

H.-K. Choi and A. Iandolino contributed equally to this work.

Current address for A. Iandolino: Monsanto Inc., Davis, CA 95616, U.S.A.

Current address for F. G. da Silva: Bio-Rad Inc., Hercules, CA 94547, U.S.A.

Corresponding author: D. R. Cook; Telephone: +1.530.754.6561; E-mail: drcook@ucdavis.edu

* The $\boldsymbol{e}$-Xtra logo stands for "electronic extra" and indicates that six supplementary tables, one supplementary figure, and supplementary text are published online and that Figures 1 through 8 appear in color online.

(C) 2013 The American Phytopathological Society and Saunders 1999). In many, perhaps most of these plant species, the bacterium exists as an endophytic commensal, with bacterial colonization and growth within xylem vessels occurring in plants that remain asymptomatic. Colonization of xylem vessels sets the stage for acquisition and transmission of the bacterium by a range of xylem sap-feeding insect vectors (Varela et al. 2001), which are required for movement of the bacterium within plant communities.

Unlike many related plant-pathogenic bacteria, $X$. fastidiosa has fastidious nutritional requirements and exhibits exceedingly slow growth external to either its plant or insect hosts. Moreover, its genome size is reduced by approximately $50 \%$ relative to most plant-associated bacteria, including its closest ancestor, Xanthomonas spp. Interestingly, the genome of $X$. fastidiosa lacks certain genes typical of most gram-negative plant pathogens, including those coding for type III secretion and effector proteins (Boller and He 2009; Simpson et al. 2000), consistent with a commensal strategy to avoid induction of host defense responses. These features of fastidious growth requirements and reduced genome content may reflect evolution toward an obligate commensal lifestyle.

The view of $X$. fastidios $a$ as a nonpathogenic commensal belies the fact that certain strains of $X$. fastidios $a$ are potent pathogens of numerous plant species, including grape, citrus, peach, plum, almond, oleander, elm, coffee, sycamore, oak, maple, and pear. These diseases are collectively referred to as leaf scorch diseases, based on the common symptom of necrotic tissue at the periphery of pathogen-infected leaves. It may be noteworthy that a great majority of these susceptible host species are recent introductions to regions where their leaf scorch diseases now occur; similarly, studies of bacterial diversity suggest that certain pathogenic strains of $X$. fastidiosa are recent introductions into new geographical regions (Nunney et al. 2010). There is growing evidence from the study of mammalian hosts that colonization by nonadapted commensals (so-called "frustrated commensals") can manifest as persistent inflammatory disease (Nussbaum and Locksley 2012); we speculate that a similar situation might underlie the $X$. fastidiosa leaf scorch syndrome in plants. Along these same lines, Lindow and colleagues (Baccari and Lindow 2011) hypothesized that leaf scorch disease occurs in plant species where bacterial spread and multiplication exceed levels that are normally kept in check by a density-dependent regulatory circuit (Chatterjee et al. 2008a and b; Newman et al. 2004). Excessive bacterial colonization of the xylem has long been hypothesized to occlude vessels, resulting in reduced water conductance that predisposes plants to drought-stress conditions and symptom development.

If the above speculations are correct-that i) X. fastidiosa is a frustrated commensal in nonadapted hosts, ii) X. fastidiosa avoids triggering of host defenses, and iii) development of leaf 
scorch disease is a consequence of reduced water conductance-then characterizing disease progression at the transcriptional and physiological levels should reveal corresponding molecular signatures. Here, we test these hypotheses in the context of Pierce's disease of grape.

Pierce's disease of grape is among the most widely recognized of the leaf scorch diseases, and is one of the most destructive diseases of grapevines (Purcell and Hopkins 1996). The disease is prevalent in the continental United States, from Florida to California, as well as in Central and South America. Recent work by Nunney and colleagues (2010) supports the conclusion that the grape strain was introduced to the United States in a single event from South America since the time of European migration to the western hemisphere. The threat of Pierce's disease increased with the more recent arrival of a highly mobile insect vector, the glassy-winged sharp shooter (Homalodisca vitripennis). X. fastidiosa is transmitted to host plants during xylem sap feeding by the insect vector, multiplies, and then spreads from the inoculation site to colonize the xylem (Baccari and Lindow 2011).

A long-standing but relatively untested hypothesis states that Pierce's disease is a consequence of obstructed water flow,

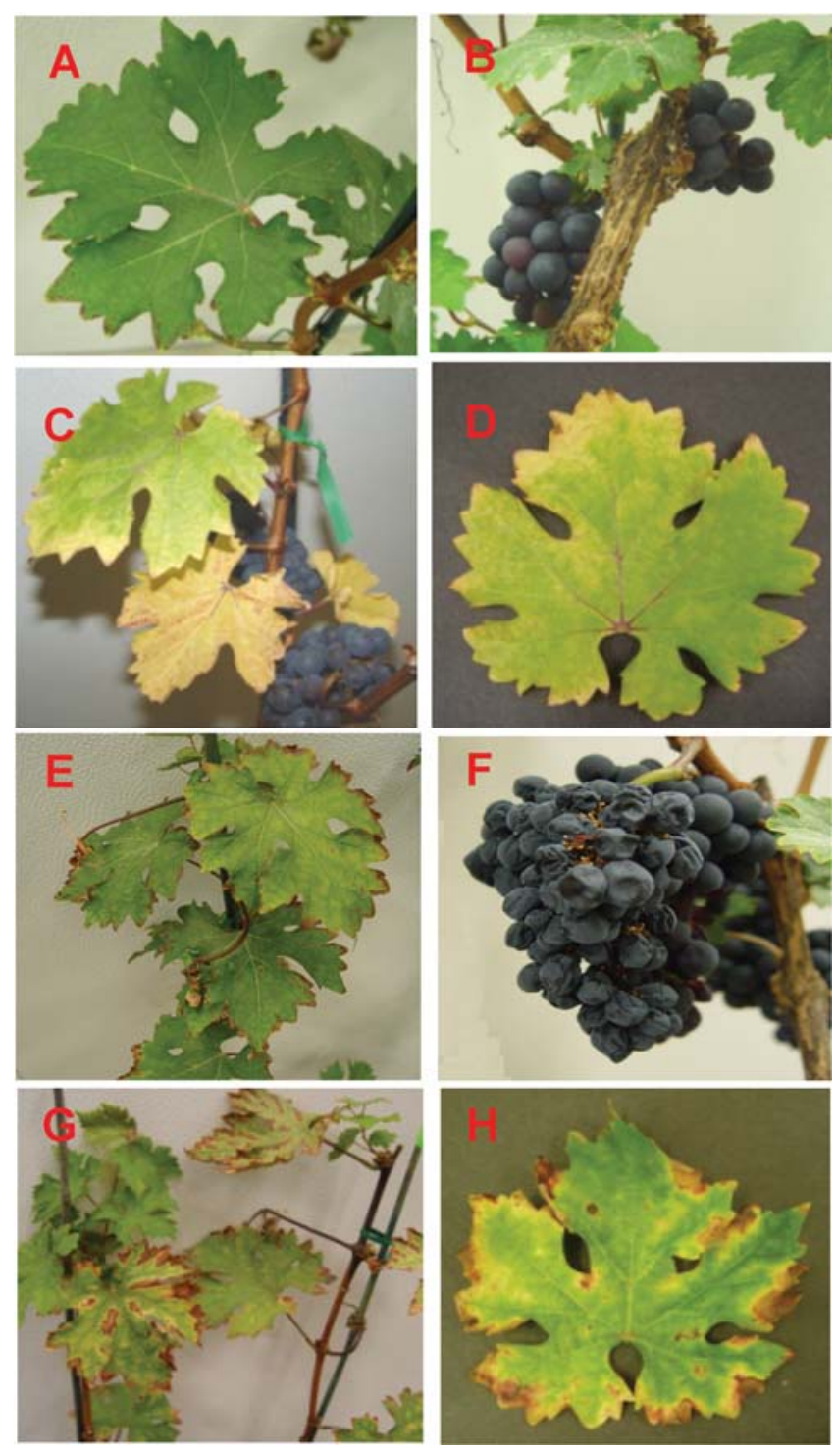

Fig. 1. Foliar symptoms of healthy, Xylella-infected, and drought-stressed vines. 'Cabernet Sauvignon' leaves 8 weeks after treatment. $\mathbf{A}$ and $\mathbf{B}$, mock inoculated control; $\mathbf{C}$ and $\mathbf{D}$, severe drought stress; $\mathbf{E}$ and $\mathbf{F}$, Xylella infection; $\mathbf{G}$ and $\mathbf{H}$, Xylella inoculation and severe drought stress. due to both the activities of the bacterium and the production of host-derived tyloses and gums in infected xylem vessels (Hopkins 1989). Thus, it is frequently observed that wellwatered plants develop reduced symptoms relative to waterstressed plants. Moreover, although high bacterial titers are frequently observed early in the season, disease symptoms are typically not evident until late summer, when temperatures are high and water availability is reduced. Nevertheless, a causal relationship between Xylella infection and water stress has not been established, and little is known about the nature of the host response during Pierce's disease. It is noteworthy, for example, that the "water-stress" hypothesis may not explain the absence of symptoms in tolerant genotypes of wild Vitis spp., which can be heavily infected by the pathogen but without disease. Thus, a competing hypothesis suggests that Pierce's disease symptoms are the consequence of an inappropriate host response to an otherwise commensal bacterium. Understanding the relationship between Pierce's disease and vine water status is not of academic interest only, because imposition of vine water deficit is used in viticulture to restrict berry size and, thereby, modify wine sensory attributes (Castellarin et al. 2007; Matthews et al. 1990). Thus, it is possible that there are tradeoffs between disease progression and viticultural practices.

Here, we test the water-stress hypothesis of Pierce's disease by characterizing the host's transcriptional and physiological responses to Xylella infection, moderate or severe water deficit, or a combination of infection and water deficit. We observed both that the pathogen induces drought stress and that externally imposed drought stress potentiates disease development. Changes to host gene transcription suggest an amalgamated response consisting of the sequential activation of drought stress and defense responses, as well as the downregulation of numerous pathways related to photosynthesis and growth. Based on these observations, we propose a model for Pierce's disease development that incorporates negative interactions between signaling pathways for abiotic and biotic stress.

\section{RESULTS}

\section{Experimental design to test the effect} of plant water status on Pierce's disease.

With the goal of testing the relationship between plant water status and the development of Pierce's disease symptoms, we designed an experiment to compare i) pre-symptomatic and post-symptomatic infected host tissue, ii) drought-stressed versus diseased individuals, and iii) the interaction between drought stress and pathogen infection. To normalize transpiration capacity among individuals, vines were pruned to produce a uniform shoot architecture. Water use was calculated by watering five plants to field capacity, and a mini-lysimeter was used to define $100 \%$ estimated water use. Throughout the remainder of the experiment, plants were watered at either $100 \%$ water usage (water sufficient), 50\% water usage (mild drought), or $25 \%$ water usage (severe drought).

The experiments presented below focused on leaf tissue sampled prior to and after the onset of symptoms at 4 and 8 weeks post-treatment, respectively. The onset of berry ripening, or veraison, a key developmental landmark in cultivated grape, occurred at approximately 5 weeks post-treatment; thus, throughout this article, the terms pre-veraison and post-veraison are used synonymously with the 4-week and 8-week time points.

\section{Disease symptoms and physiological perturbations} are enhanced in $X$. fastidios $a$-infected, water-stressed plants.

Both $X$. fastidiosa-inoculated and drought-stressed grapevines developed foliar symptoms at 6 weeks postinoculation (Fig. 1) but the patterns of leaf symptoms were readily distin- 
guished. Disease symptoms consisted of characteristic necrosis at the leaf margin, accompanied by adjacent chlorotic tissue. By contrast, drought-stressed vines developed minimal necrosis, while predominant chlorosis often spread throughout individual leaves. Grapevines treated with both pathogen inoculation and water deficit exhibited more severe symptoms than either treatment individually and, similar to $X$. fastidiosa infection alone, the symptoms of doubly treated plants appeared primarily at the leaf margins. Berry mummification, which is a classic symptom of Pierce's disease, was evident in X. fastidi$o s a$-inoculated plants but not in drought-stressed vines.
Physiological measurements-that is, pre-dawn leaf water potential $\left(\psi_{\mathrm{pd}}\right)$, net $\mathrm{CO}_{2}$ assimilation $\left(A_{\mathrm{n}, \max }\right)$, stomatal conductance $\left(g_{\mathrm{s}}\right)$, and transpiration rate $(E)$-were conducted to characterize the impact of water deficit and $X$. fastidiosa treatments. In healthy plants, deficit irrigation had a significant effect on leaf gas exchange and vine water status at both pre- and post-veraison stages (Table 1). In general, for the drought-only treatments, parameters were more impacted by severe drought than mild drought, and the differences between water-sufficient and drought-stressed plants were greatest in the early, pre-veraison samples. These results confirm that the

Table 1. Survey of gas exchange and plant water status parameters ${ }^{\mathrm{x}}$

\begin{tabular}{|c|c|c|c|c|c|c|c|c|c|c|}
\hline \multirow[b]{2}{*}{ Treatment $^{\mathrm{y}}$} & \multicolumn{4}{|c|}{ Early } & \multicolumn{4}{|c|}{ Late } & \multirow[b]{2}{*}{$\mathrm{Ci} / \mathrm{Ca}$} & \multirow[b]{2}{*}{$\mathrm{dC}_{13}^{\mathrm{z}}$} \\
\hline & $\begin{array}{c}\Psi_{\text {pd }} \\
(\mathbf{M P a})\end{array}$ & $\begin{array}{c}A_{\mathrm{n}, \max }(\mu \mathrm{mol} \\
\left.\mathbf{m}^{-2} \mathbf{s}^{-1}\right)\end{array}$ & $\begin{array}{c}g_{\mathrm{s}}(\mathbf{m m o l} \\
\left.\mathrm{m}^{-2} \mathrm{~s}^{-1}\right)\end{array}$ & $\begin{array}{c}E(\mathbf{m m o l} \\
\left.\mathbf{m}^{-2} \mathbf{s}^{-1}\right)\end{array}$ & $\begin{array}{l}\Psi_{\mathrm{pd}} \\
(\mathbf{M P a})\end{array}$ & $\begin{array}{c}A_{\mathrm{n}, \max }(\mu \mathrm{mol} \\
\left.\mathrm{m}^{-2} \mathbf{s}^{-1}\right)\end{array}$ & $\begin{array}{c}g_{\mathrm{s}}(\mathrm{mmol} \\
\left.\mathrm{m}^{-2} \mathrm{~s}^{-1}\right)\end{array}$ & $\begin{array}{c}E(\mathbf{m m o l} \\
\left.\mathbf{m}^{-2} \mathbf{s}^{-1}\right)\end{array}$ & & \\
\hline \multicolumn{11}{|l|}{ MD } \\
\hline $\mathrm{N}$ & $-0.10 \mathrm{a}$ & $19.9 \mathrm{a}$ & $319 a$ & $3.6 \mathrm{a}$ & $-0.33 \mathrm{a}$ & $25.9 \mathrm{a}$ & $203 a$ & $3.7 \mathrm{a}$ & $0.79 \mathrm{a}$ & $\ldots$ \\
\hline $\mathrm{D}$ & $-0.20 \mathrm{~b}$ & $15.3 \mathrm{~b}$ & $303 \mathrm{a}$ & $3.5 \mathrm{a}$ & $-0.37 \mathrm{a}$ & $21.0 \mathrm{ab}$ & $160 \mathrm{a}$ & $3.1 \mathrm{a}$ & $0.79 \mathrm{ab}$ & $\ldots$ \\
\hline I & $-0.10 \mathrm{a}$ & $20.3 \mathrm{a}$ & $343 \mathrm{a}$ & $3.7 \mathrm{a}$ & $-0.43 \mathrm{ab}$ & $19.0 \mathrm{ab}$ & $55 \mathrm{~b}$ & $1.3 \mathrm{~b}$ & $0.55 \mathrm{bc}$ & $\ldots$ \\
\hline ID & $-0.21 \mathrm{~b}$ & $18.0 \mathrm{ab}$ & $296 \mathrm{a}$ & $3.5 \mathrm{a}$ & $-0.58 \mathrm{~b}$ & $16.9 \mathrm{~b}$ & $40 \mathrm{~b}$ & $1.0 \mathrm{~b}$ & $0.37 \mathrm{c}$ & $\ldots$ \\
\hline \multicolumn{11}{|l|}{ SD } \\
\hline $\mathrm{N}$ & $-0.17 \mathrm{a}$ & $18.3 \mathrm{ab}$ & $273 \mathrm{a}$ & $3.5 \mathrm{a}$ & $-0.26 \mathrm{a}$ & $23.5 \mathrm{a}$ & $285 \mathrm{a}$ & $4.6 \mathrm{a}$ & $0.83 \mathrm{a}$ & $-29.1 \mathrm{a}$ \\
\hline $\mathrm{D}$ & $-0.28 b c$ & $13.9 \mathrm{~b}$ & $145 \mathrm{~b}$ & $2.3 \mathrm{~b}$ & $-0.48 \mathrm{~b}$ & $19.0 \mathrm{ab}$ & $279 a$ & $4.4 \mathrm{a}$ & $0.87 \mathrm{a}$ & $-29.5 \mathrm{a}$ \\
\hline ID & $-0.24 a b$ & $21.8 \mathrm{a}$ & $277 \mathrm{a}$ & $3.6 \mathrm{a}$ & $-0.47 \mathrm{~b}$ & $11.3 \mathrm{bc}$ & $65 \mathrm{~b}$ & $1.2 \mathrm{~b}$ & $0.51 \mathrm{~b}$ & $-28.5 \mathrm{a}$ \\
\hline $\mathrm{D}$ & $-0.27 b c$ & $18.0 \mathrm{ab}$ & $137 \mathrm{~b}$ & $2.2 \mathrm{~b}$ & $-0.59 \mathrm{~b}$ & $7.4 \mathrm{c}$ & $13 \mathrm{~b}$ & $0.3 \mathrm{~b}$ & $0.38 \mathrm{~b}$ & $-27.6 \mathrm{~b}$ \\
\hline
\end{tabular}

${ }^{\mathrm{x}}$ Early, 4 weeks after treatment; Late, 8 weeks after treatment. Measured values with differing alphabetical subscripts are significantly different at $\alpha=0.1$ according to Tukey's test.

${ }^{\mathrm{y}} \mathrm{MD}$, mild drought (50\% of control); $\mathrm{SD}$, severe drought (25\% of control); N, water=sufficient, healthy controls; D, drought treatment; I, Xylella fastidiosa infection treatment; ID, $X$. fastidiosa infection and drought treatment combined.

${ }^{\mathrm{z}}$ Values for carbon isotope discrimination $\left(\mathrm{dC}_{13}\right)$ are average values for mild and severe drought.

A

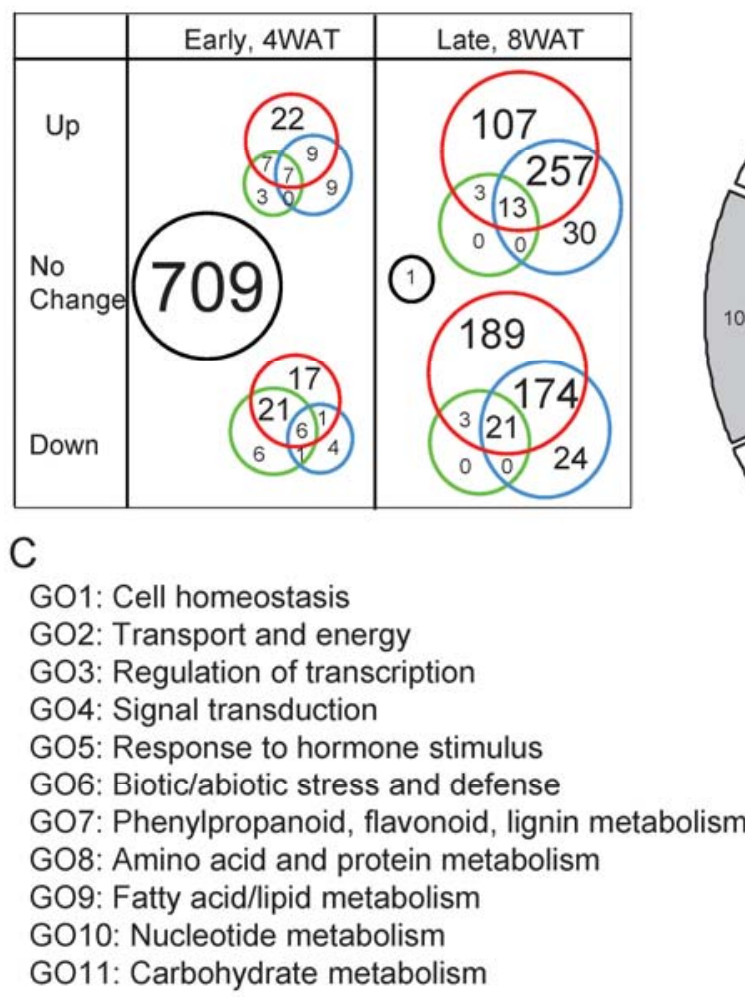

B

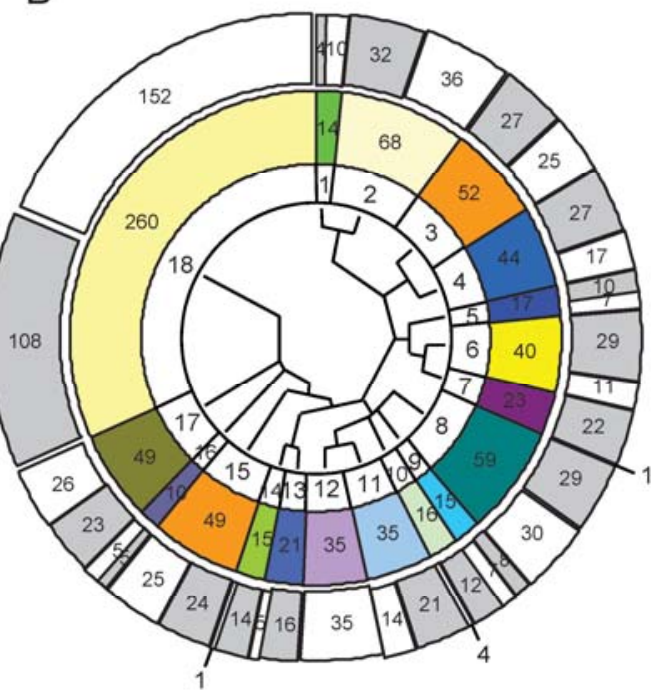

G012: Photosynthesis

G013: Cell wall modification

G014: Aging, ripening and cell death

G015: Cellular and physiological processes

G016: Development

G017: Unknown ontology

G018: No annotation

Fig. 2. Summary of transcriptional responses for 822 differentially expressed genes. A, Venn diagram showing directionality and overlap of gene expression between Xylella-inoculated (blue circles), drought-treated (green circles), and doubly treated (Xylella + drought; red circles) grapevines. 4 WAT, 4 weeks after treatment; 8WAT, 8 weeks after treatment. B, Distribution of transcripts among 18 Biological Process Gene Ontology (GO) categories. Inner dendrogram depicts hierarchical relationship among GO categories, as established by the International GO Initiative. Inner circle, GO category numbers 1 to 18 ; middle circle, number of genes in each category; outer circle, distribution of transcripts between upregulated (white) and downregulated (gray) groups. By way of example, the sixth GO category ("response to biotic, abiotic, stresses/defense") is composed of 40 transcripts. Numbers in the outer circle denote upregulated (gray) or downregulated (white) transcripts. C, GO category descriptions. 
drought-stress treatments were physiologically relevant and that the two stress levels were perceived as quantitatively different by the plants.

At 4 weeks postinoculation, the physiological values for infected individuals were not significantly different from healthy, water-sufficient controls (Table 1). Moreover, plants doubly treated with drought stress and infection were equivalent in all measured parameters to plants treated with drought stress alone. The fact that the pathogen did not measurably impact gas exchange or plant water status in pre-veraison vines is consistent with the absence of visible symptoms of disease on these same individuals.

By contrast, at 8 weeks postinoculation, when disease symptoms were clearly evident, $X$. fastidiosa infection impacted all measured values (Table 1$)$. In the cases of $\psi_{\mathrm{pd}}$ and $A_{\mathrm{n}, \max }, X$. fastidiosa infection produced effects equivalent to drought treatment alone. However, for $g_{\mathrm{s}}$ and $E, X$. fastidiosa infection imposed significantly greater physiological stress than drought alone, and doubly treated vines tended to be more impacted than those treated with infection alone.

Despite a significant reduction in $\psi_{\mathrm{pd}}$ in healthy, severedrought-treated individuals, reduced water availability had no significant impact on $g_{\text {s }}$ or $E$. By contrast, $X$. fastidiosa infection alone was correlated with significant reductions to both $g_{\mathrm{s}}$ and $E$ (Table 1 , severe drought, late). Thus, $X$. fastidiosa had a considerably greater impact on leaf gas exchange than did drought treatment but a similar impact on $\psi_{\mathrm{pd}}$. The effect of $X$. fastidiosa infection on $g_{\mathrm{s}}$ is also reflected in changes observed in carbon isotope discrimination values $\left(\mathrm{dC}_{13}\right)$, which indicate the cumulative impact of treatments.

Taken together, these results demonstrate that, in symptomatic plants, i) $X$. fastidiosa infection significantly impacts both vine water status and photosynthesis-related parameters, ii) infection and drought combine to create both more severe disease symptoms and physiological perturbations than either stress alone, and iii) $X$. fastidiosa infection impacts pre-dawn water potential similar to severe drought stress but has a markedly greater impact on leaf gas exchange and photosynthesis.

\section{Infection by $X$. fastidios $a$ and water deficit cause redirection of gene expression.}

Transcriptional profiling was conducted using the Affymetrix Vitis vinifera (grape) Genome Array V. 1.0. Differentially expressed genes were identified using a moderated $t$ test (fold change $\geq 2$ ), with Benjamini-Hochberg adjustment for false discovery rate $(P \leq 0.05)$. Using these thresholds and comparing all possible contrasts within an irrigation treatment, we circumscribed 822 differentially expressed genes. Genes were further classified according to inferred biological process, using the terminology and hierarchical relationships of the Gene Ontology (GO) consortium. Seventeen different categories were sufficient to describe 562 genes (Figs. 2B and 3). Annota-
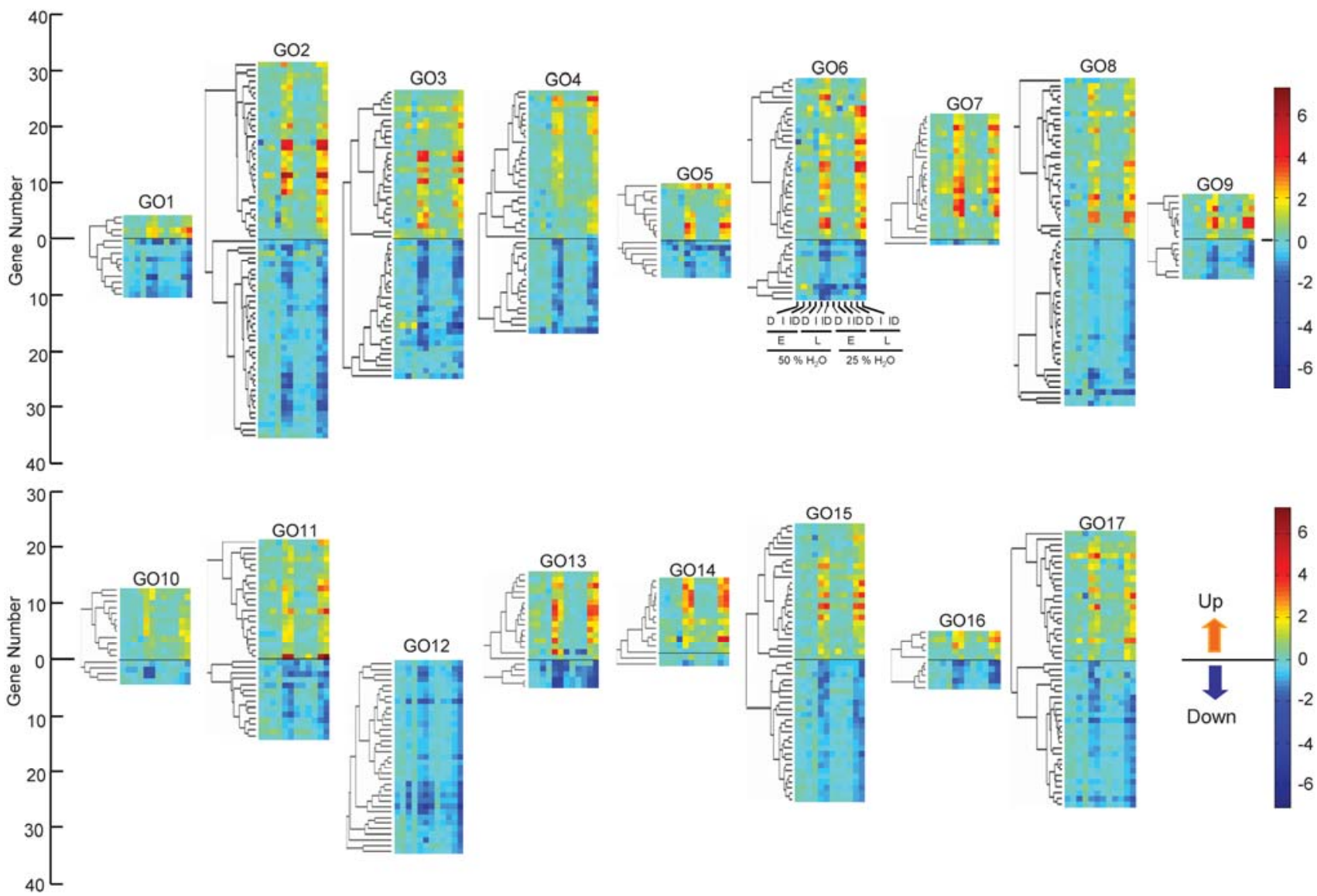

Fig. 3. Two-dimensional hierarchical cluster of Xylella fastidiosa and drought-responsive genes. In total, 562 genes are represented in the figure and organized according to 17 Gene Ontology (GO) categories. The correlation between color and $\log 2$ fold-change is represented in the right side heat bar graphic. The underlying numerical expression data and gene annotations, along with the expression identification (ID) numbers assigned to each transcript can be found in Supplementary Table S1. Expression ID numbers were assigned to each transcript to facilitate discussionand refer to the position within the diagram and directionality of expression; thus, GO1-U1 is the first upregulated gene above the middle axis in GO category 1, while GO1-D1 is the first downregulated gene below the middle axis in GO category 1. Heat maps within each GO category are organized horizontally according to treatment, as indicated by example below GO6. D, drought-stressed; I, X. fastidiosa-inoculated, ID, double treatment of X. fastidiosa infection and drought stress; E, early (4 weeks after treatment); $\mathrm{L}$, late (8 weeks after treatment). 
tion could not be obtained for 260 genes, which were classified in an eighteenth category described as "unknown function".

Consistent with physiological measurements (Table 1), fourweek-old $X$. fastidiosa-infected plants possessed a transcriptional profile that was similar to that of healthy, water-sufficient individuals (Fig. 2A), differing from control plants for only 37 genes. Several of these genes were also differentially expressed in individuals treated by both $X$. fastidios $a$ infection and drought treatment, providing independent support for their specific, early induction by Xylella fastidiosa. We observed a similarly mild transcriptional response to water deficit alone at four weeks post-treatment, with a total of 51 genes being differentially regulated; the majority of these drought-impacted genes were also affected by combined treatment with drought and infection but not by $X$. fastidiosa infection alone, suggestive of an early and specific transcriptional response to water deficit. Interestingly, two-thirds of the early genes modulated by water deficit were downregulated, with an enrichment for transcripts involved with photosynthesis, including multiple paralogs of chlorophyll a/b-binding protein, NADPH:protochlorophyllide oxidoreductase, and rubisco activase.

Despite the relatively mild transcriptional response observed at 4 weeks to either $X$. fastidiosa infection or water deficit, there was significant interaction between the two treatments (Fig. 2A). We observed both an increase in the number of differentially expressed genes in infected, water-stressed individuals (90 unique transcripts in total) and substantial coherence between doubly treated plants and plants receiving either treatment alone. Among the early upregulated transcripts is a highly induced 9-cis-epoxycarotenoid dioxygenase (NCED) gene. The corresponding protein is a key enzyme in the synthesis of abscisic acid (ABA), a plant hormone widely implicated in response to drought stress. This gene was significantly induced at early time points only in plants exposed to both Xylella inoculation and severe water deficit whereas, at the later 8-week time point, this transcript was induced individually by both Xylella fastidiosa and drought but most strongly in plants experiencing both stresses (Fig. 4). Frequent among plants treated by both $X$. fastidiosa and water deficit was the induction of genes associated with flavonoid synthesis, consistent with an early (i.e., 4 weeks postinoculation) host response to $X$. fastidiosa in presymptomatic individuals.

At 8 weeks postinoculation, when $X$. fastidiosa-infected plants were fully symptomatic, there was upregulation of transcripts corresponding to a range of biological processes. There was substantial symmetry of response between water-sufficient infected individuals and infected individuals that also received either mild or severe drought treatment (Fig. 2A, numerical summary, and Fig. 3, two-dimensional heat map representation organized by GO category). By contrast, there were relatively few genes induced by water deficit alone; in fact, the number of genes responding to water stress at 8 weeks was reduced compared with the 4-week time point, consistent with physiological measurements (Table 1). All of these late water-deficitrelated genes were also transcriptionally altered in plants treated with a combination of $X$. fastidiosa infection and water deficit; moreover, $85 \%$ of these genes were also differentially expressed in infected water-sufficient plants at 8 weeks, suggesting that response to water deficit is a component of the host response to $X$. fastidiosa.

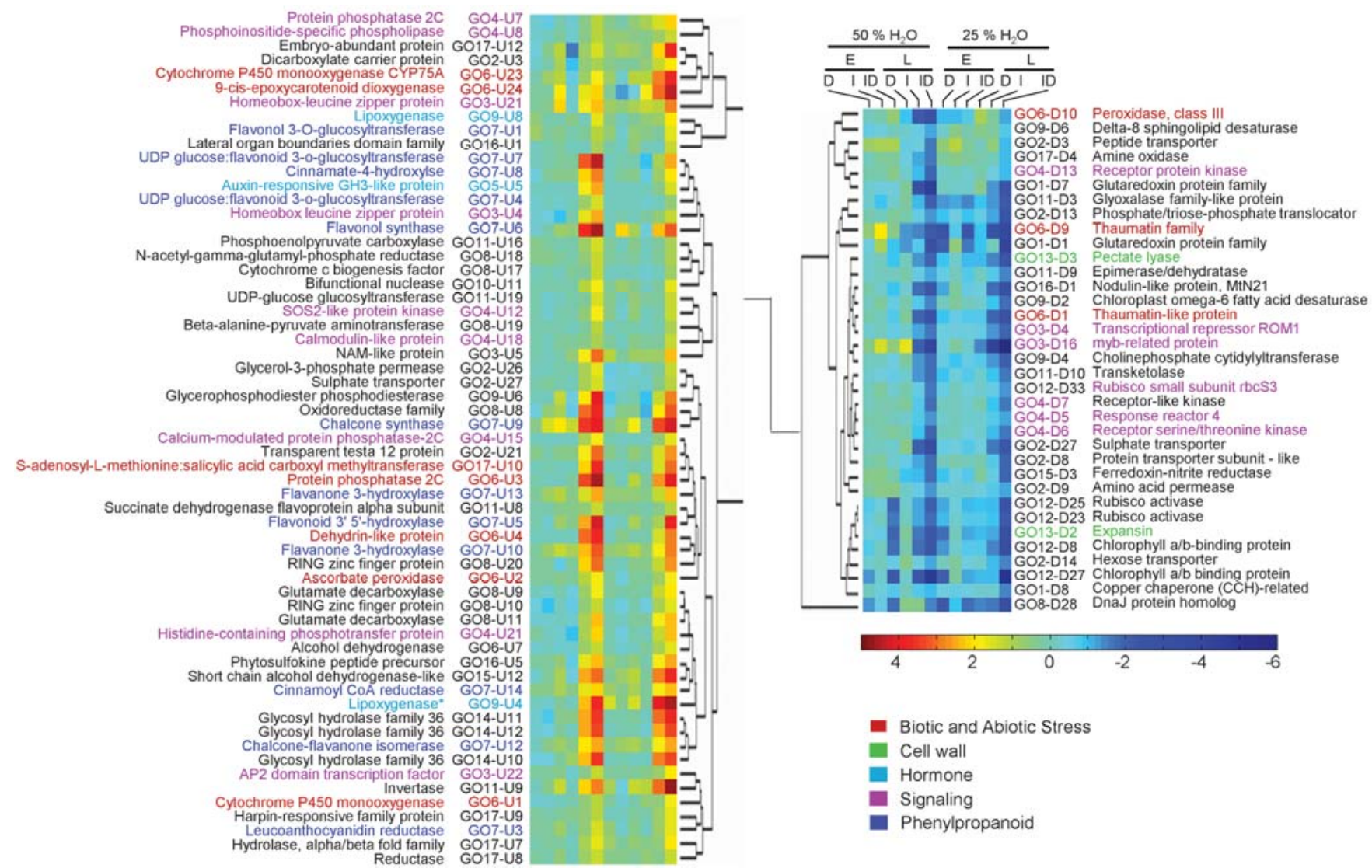

Fig. 4. Two-dimensional hierarchical cluster of genes synergistically regulated by Xylella fastidiosa and water deficit. Expression ID numbers were assigned to each transcript to facilitate discussionand refer to the position within the diagram and directionality of expression; thus, GO1-U1 is the first upregulated gene above the middle axis in GO category 1, while GO1-D1 is the first downregulated gene below the middle axis in GO category 1. Data are organized horizontally according to treatment, as indicated above the right panel. D, drought-stressed; I, X. fastidiosa-inoculated, ID, double treatment of X. fastidiosa infection and drought stress; E, early (4 weeks after treatment); L, late (8 weeks after treatment). 
Some genes respond primarily to $X$. fastidiosa infection, whereas others are most impacted by the combination of infection and water deficit.

Among the complete set of 822 genes, 553 were altered in response to $X$. fastidiosa infection. These genes could be subdivided into two categories: 415 genes that were not influ- enced by water deficit, either alone or in combination with infection, and 138 genes that exhibited greatest differential expression in plants experiencing both pathogen infection and water deficit. Among the genes responding only to Xylella infection, 103 genes had expression differences compared with healthy water-sufficient vines of at least fourfold (Fig. 5). The

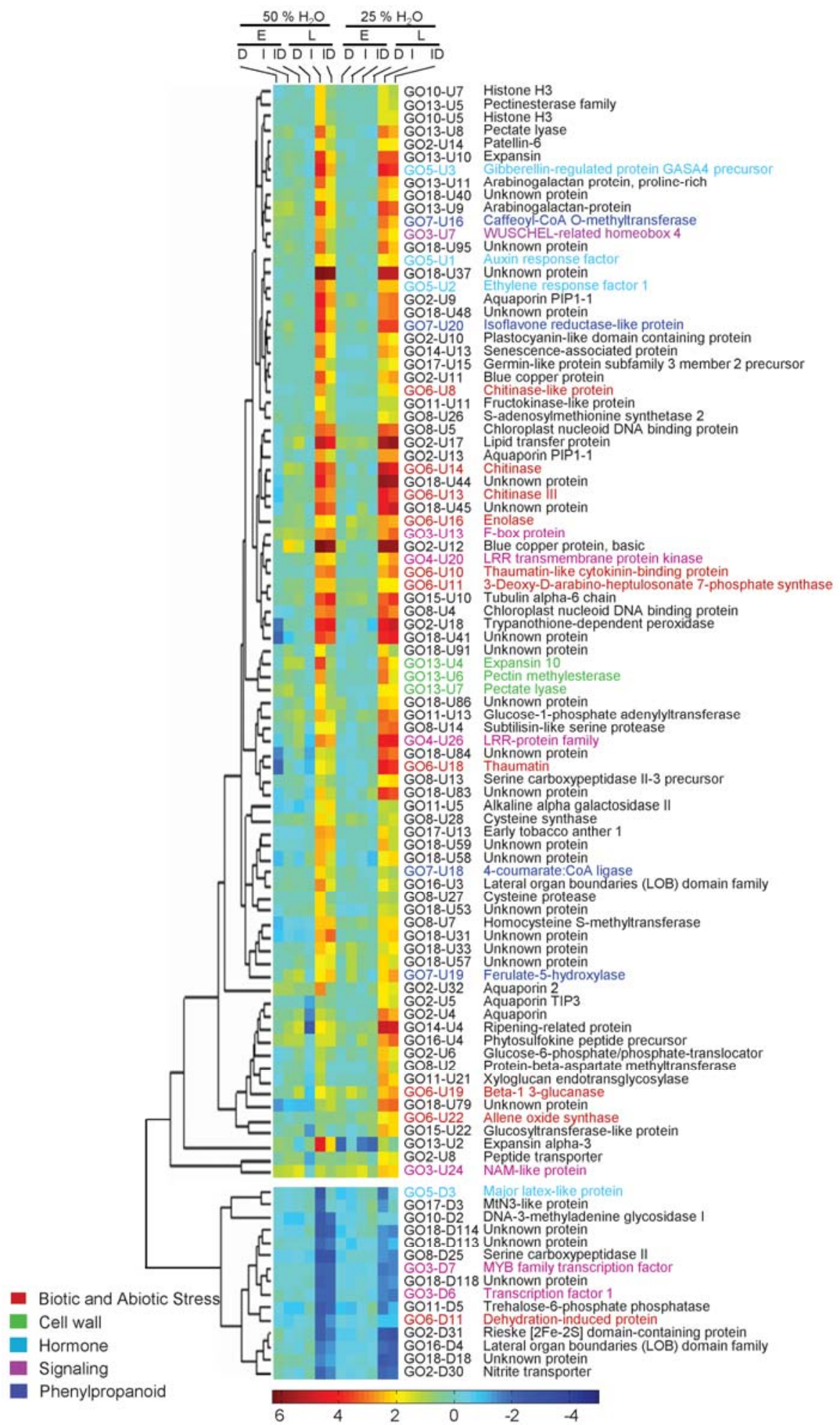

Fig. 5. Two-dimensional hierarchical cluster of genes regulated by Xylella infection. Among 415 transcripts nonsynergistically responding to Xylella infection, 103 transcripts (84 up- and 19 downregulated genes) with a minimum of fourfold change are shown. Expression ID numbers were assigned to each transcript to facilitate discussion and refer to the position within the diagram and directionality of expression; thus, GO1-U1 is the first upregulated gene above the middle axis in GO category 1, while GO1-D1 is the first downregulated gene below the middle axis in GO category 1. Data are organized horizontally according to treatment, as indicated above the heat map. D, drought-stressed; I, Xylella fastidiosa-inoculated, ID, double treatment of X. fastidiosa infection and drought stress; E, early (4 weeks after treatment); L, late (8 weeks after treatment). 
predominant functional category among this highly induced, $X$. fastidiosa-specific transcript set was response to biotic and abiotic stress (Supplementary Table S2), with the majority of such transcripts encoding pathogenesis-related (PR) proteins, including chitinases, $\beta$-1,3-glucanases, thaumatin-like proteins, and two lipid transfer proteins (classified into GO2 in this study). Several $X$. fastidiosa-induced transcripts encode signaling proteins (Supplementary Table S3), including a leucine-rich repeat (LRR) kinase and an ethylene response transcription factor, that potentially mediate host transcriptional changes to the bacterium. A particularly noteworthy aspect of the transcriptional response to Xylella fastidiosa is a set of seven distinct aquaporin transcripts, five of which exceeded the fourfold cutoff used in Figure 5. Together, these genes represent three of the five classes of plant aquaporins (plasma membrane intrinsic proteins, tonoplast intrinsic proteins and NOD26-like major intrinsic proteins). Interestingly, none of these aquaporin transcripts were induced by water-deficit treatment alone, and their induction in $X$. fastidiosa-infected plants was consistently equal to or exceeded that observed in plants treated by both $X$. fastidios $a$ and water stress.

The observation of a set of 138 genes with greatest differential expression in infected, drought-treated individuals suggests an interaction between the two stressors and is consistent with enhanced physiological and disease symptoms on these same individuals (Table 1 and Figure 1, respectively). In contrast to genes that are responsive to $X$. fastidiosa alone, none of the synergistic transcripts encode classical PR proteins; instead, several of these transcripts encode proteins implicated in abiotic stress. Such transcripts include two paralogs of NCED (upregulated four- to 16-fold), noted above as a key enzyme in ABA biosynthesis, which is well known for its function in drought and other abiotic stress responses (Iuchi et al. 2000); and a dehydrin-like protein implicated in response to water stress (Borovskii et al. 2002). Further evidence of a response to abiotic stress among the synergistic set of genes is the in- duction of a calcineurin B-like-interacting protein kinase (CIPK) (GO4-U12), as well as several proteins that could potentially mediate calcium signaling during drought responses. Moreover, three additional CIPK paralogs (GO4-U1, U3, and $\mathrm{U13}$ ) and an ABA-activated protein kinase homolog (GO4U11) (Kobayashi et al. 2004) were induced by $X$. fastidiosa infection but not synergistically with water deficit. Two transcripts encoding related methyltransferases (GO17-U10 and GO17-U5) were also highly induced in Xylella-infected leaves. The expression of GO17-U10 in particular was further enhanced by the combination of Xylella infection and water deficit. GO17-U10 is an equally close homolog of two Arabidopsis proteins, BSMT1 and JMT1, which are required for methylsalicylate (MeSA) and methyl jasmonate (MeJA) production, respectively (Attaran et al. 2009; Chen et al. 2003; Liu et al. 2010; Seo et al. 2001).

The largest single category of "synergistic" transcripts consisted of those involved in flavonoid metabolism. Flavonoid pathway genes are unique among the set of 822 genes, because $>95 \%$ of all transcripts in this category are upregulated (Fig. 3) and represent a substantial majority of flavonoid pathway enzymes (Fig. 6). A known regulator of flavonoid metabolism, an MYB (myeloblastosis) transcription factor (GO3-U15) which controls anthocyanin biosynthesis through its regulation of the UDP-glucose:flavonoid 3-O-glucosyltransferase gene, was also strongly upregulated (more than eightfold) in $X$. fastidiosainfected leaves. Interestingly, the parallel branch of phenylpropanoid metabolism leading to lignin biosynthesis, as well as an isoflavone reductase paralog potentially leading to the production of anti-microbial phytoalexins, were strongly induced by $X$. fastidiosa but not further influenced by water stress (Fig. 5). Enhanced transcription for these secondary metabolic pathways was accompanied by upregulation of 3-deoxy-D-arabinoheptulosonate-7-phosphate synthase, a key regulator of shikimate metabolism, which interconnects aromatic amino acid biosynthesis with the phenylpropanoid pathway.

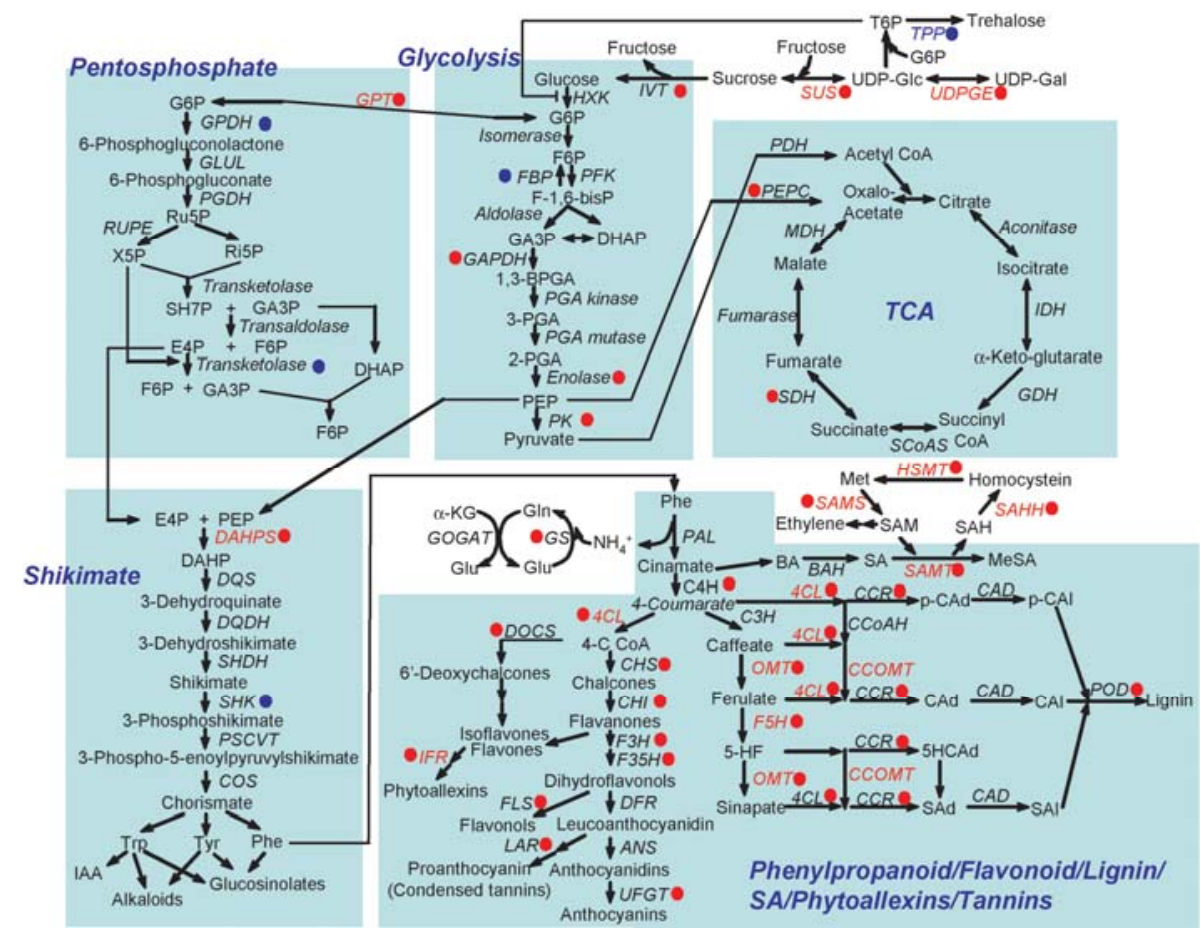

Fig. 6. Integrated view of transcriptional responses for key primary and secondary biochemical pathways. Arrows connect metabolites. Enzymes encoded by measured transcripts are denoted adjacent to arrows in uppercase italic letters. Red circles denote upregulated genes and blue circles denote downregulated genes. Genes with red-colored text are involved in lignin and phytoalexin biosynthesis and were specifically induced by Xylella fastidiosa. Abbreviations for biochemical matabolites and enzymes follow commonly accepted terminology and are listed in full detail in the Supplementary Text published online. 

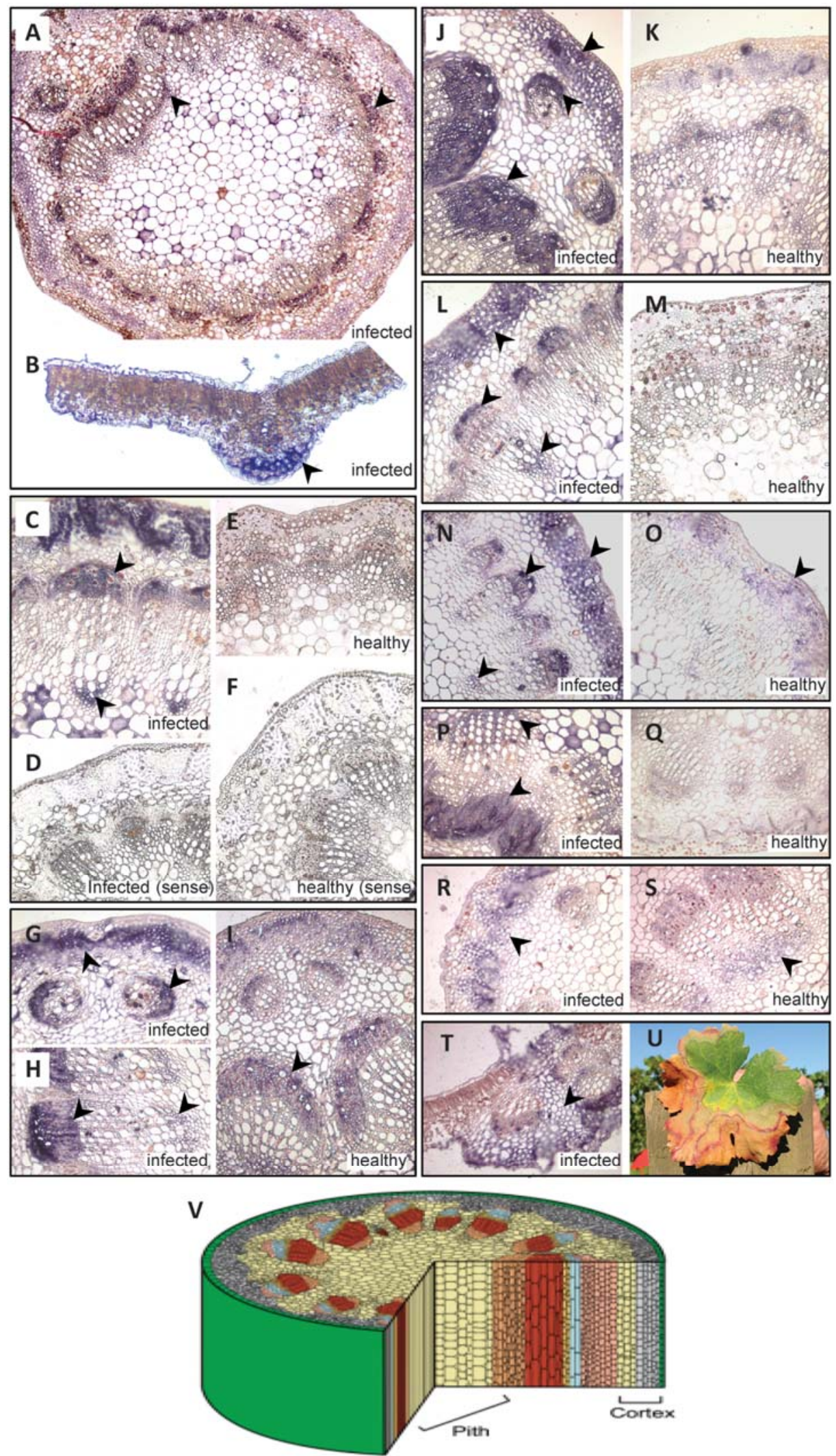

Fig. 7. In situ localization of Xylella fastidiosa-induced transcripts in Vitis vinifera. Images are cross sections of $\mathbf{A}$ and $\mathbf{C}$ to $\mathbf{S}$, petiole; and $\mathbf{B}$, T, and $\mathbf{U}$, leaf tissue of healthy and Xylella-infected grape 'Cabernet Sauvignon'. Transcript hybridization is indicated by blue-purple coloration, marked by arrowheads in the individual panels. A to $\mathbf{S}$, Greenhouse-grown plants; $\mathbf{T}$ and $\mathbf{U}$, field-collected specimen from Napa Valley. Individual specimens were hybridized with either antisense or sense transcripts of nine different Xylella-induced genes. A and B, Uncharacterized protein, ref seq ID XM002284757. C to F, Class IV chitinase Gene Ontology (GO)6-U8. G to I, Chalcone synthase GO7-U9. J and K, Flavonol synthase GO7-U6. L and M, Flavonoid 3,5 hydroxylase GO7U5. N and $\mathbf{O}$, Aquaporin PIP1-1 GO2-U9. P and Q, Receptor-like kinase GO4-U20. R to T, Thaumatin GO6-U18. U, Field-sampled leaf analyzed in T. V, Anatomical reference to facilitate interpretation of microscope images. Colors demark different tissues within the grape petiole: green, epidermis; gray, collenchyma; nude, schlerenchyma; blue, phloem; orange, protoxylem; gold, cambium; yellow, parenchyma; red, xylem. All hybridizations shown are from antisense probes, with the exception of panels $\mathrm{D}$ and $\mathrm{F}$, which are exemplary of sense probes. 
Validation of microarray data by real-time reversetranscriptase polymerase chain reaction.

To validate the microarray data, we performed reverse-transcriptase polymerase chain reaction (RT-PCR) analysis with 20 selected grape genes (Supplementary Fig. S1; Supplementary Table S4). Expression patterns were similar to those observed in microarray data. Because real-time RT-PCR provides accurate quantification of transcript levels, we were also able to verify the proposed synergistic expression of genes. For example, we confirmed that four genes associated with flavonoid biosynthesis - namely, leucoanthocyanidin dioxygenase, flavonol synthase, flavonoid 3',5'-hydroxylase, and isoflavone reductase-like protein-were not significantly affected by drought but were strongly induced in infected vines.

\section{Gene transcription largely originates} from vascular-associated tissues.

The same set of genes used for real-time PCR was also used for in situ hybridization experiments to localize gene expression in petiole and leaf tissue (Fig. 7; Supplementary Table $\mathrm{S} 5)$. In general, there was significant similarity in the tissue distribution of transcripts, regardless of the gene under analysis. Moreover, compared with healthy individuals, diseased individuals had both higher levels of transcript and transcripts were often distributed among a broader set of tissues. Thus, in Xylella-infected petioles, expression was observed primarily within collenchyma, phloem and phloem schlerenchyma, and xylem-associated cells in the vicinity of protoxylem. A complete petiole cross section, hybridized with an unclassified transcript (XM002284757) that is expressed most strongly in phloem and protoxylem tissue, with lower but detectable expression in cortical collenchyma is shown in Figure 7A. Similarly, a class IV chitinase (Fig. 7C to F) was highly induced in collenchyma, phloem and phloem schlerenchyma, and protoxylem tissues of $X$. fastidiosa-infected petioles. We examined a limited number of leaf cross sections (Fig. 7B and T) and observed transcripts primarily in collenchyma tissue, though expression in phloem and protoxylem cells was occasionally observed (Fig. 7T).

\section{DISCUSSION}

Here, we test the water-stress hypothesis for Pierce's disease by monitoring transcriptional and physiological changes in susceptible $V$. vinifera challenged by $X$. fastidiosa infection, moderate or severe water deficit, or a combination of $X$. fastidiosa infection and water deficit. We hypothesized that, if Pierce's disease is largely a consequence of Xylella-induced xylem blockage, then the transcriptional signature of infected plants should resemble that of drought-stressed plants. Alternatively, water deficit induced by $X$. fastidiosa-associated xylem blockage might be quantitatively and qualitatively distinct from water deficit induced through reduced irrigation, and transcriptional profiling might be informative of such differences. In either case, if water stress potentiates disease development, then one might expect an enhanced transcriptional response in infected plants that are also water stressed, regardless of the overlap in the transcriptional signatures of the two stresses imposed independently. We observed aspects of both outcomes, suggesting a bifurcating host response in symptomatic leaves, with i) classical defense-against-pathogen genes and genes coding for synthesis of biotic stress hormones activated largely, but not exclusively, by Xylella infection independent of drought stress; and ii) genes known to function in drought-stress tolerance and the synthesis of abiotic stress hormones activated most strongly by the interaction of Xylella infection and drought.
Plants treated with water deficit alone displayed characteristics of physiological acclimation and had a relatively mild transcriptional response, consistent with characterization of $V$. vinifera as a relatively drought-tolerant species (Cramer et al. 2007). The most conspicuous feature of this drought response was downregulation of genes related to photosynthesis, consistent with the activation of stress-mediated decay (Park et al. 2012).

Interestingly, Xylella infection alone had a significantly greater impact on physiological parameters related to drought stress than did water deficit. Moreover, despite the mild response of vines to deficit irrigation, water deficit markedly increased the magnitude of Xylella-induced changes, including greater reductions to pre-dawn water potential and an almost complete loss of gas exchange and net $\mathrm{CO}_{2}$ assimilation. Thus, water deficit exacerbates the host response during Pierce's disease, and this interaction between infection and water deficit was evident even prior to the onset of disease symptoms both at the physiological level and in terms of gene transcription.

Xylella infection induced a range of transcripts whose products strongly suggest that Xylella infection causes drought stress, including the induction of genes for ABA synthesis but also numerous components of water-stress signaling (e.g., numerous CIPK homologs and components of calcium signaling pathways) and genes for osmotic adjustment. ABA mediates responses to a wide range of environmental factors and is particularly important as a mediator of water-stress adaptation (Bonetta and McCourt 1998; Fujita et al. 2004). The early (i.e., 4 weeks postinoculation) upregluation of an NCED homolog, coding for a key enzyme in ABA biosynthesis, highlights the conclusion that drought stress precedes disease development. Indeed, Cramer and associates (2007) observed early upregulation of NCED transcription in grapevines as early as 12 days post-water deficit. ABA promotes water uptake and cell-tocell flow by inducing aquaporin genes (Hose et al. 2000) and, here, we observed the induction of multiple aquaporin transcripts by Xylella infection alone (Fig. 5). One such aquaporin was analyzed by in situ hybridization, revealing strong induction in phloem and protoxylem as well as in collenchyma tissue (Fig. $7 \mathrm{~N}$ and $\mathrm{O}$ ). Additional evidence for Xylella-induced drought stress is the upregulation of two galactinol synthase (GOLS) paralogs (GO11-U1 and GO11-18), with GO11-U1 induced over 50- and 120-fold by X. fastidiosa and X. fastidiosa combined with water deficit, respectively. GOLS mediates the synthesis of galactinol and raffinose, known osmoprotectants that enhance tolerance to drought stress (Taji et al. 2002).

Many of the defense-related PR genes as well as genes for lignin and phytoalexin production were induced by Xylella fastidiosa but not further induced by the added stress of water deficit. Moreover, we observed 51 genes that were regulated by both drought and $X$. fastidiosa but with opposing directionality (Supplementary Table S6). Taken together, these observations suggest that the plant may be able to discern the bacterium's presence distinct from drought stress. Studies to date indicate that $X$. fastidiosa is strictly confined to the xylem apoplast; therefore, the question arises of how the host might perceive the pathogen's presence. Although mature xylem is nonliving it is, nevertheless, a physiologically active compartment, containing specific proteins and plant hormones whose concentrations vary based on environmental factors (Perez-Alfocea et al. 2011; Shatil-Cohen et al. 2011; Wilkinson and Davies 2002). For example, PR proteins homologous to those identified in this study, including class IV chitinases, $\beta$-1,3-glucanases, and thaumatin proteins, are frequently observed in xylem sap, as is ABA. Contact pits between xylem-associated cells and vessels provide an active interface between the symplastic and apoplastic compartments (van der Schoot and van Bel 1989) and, 

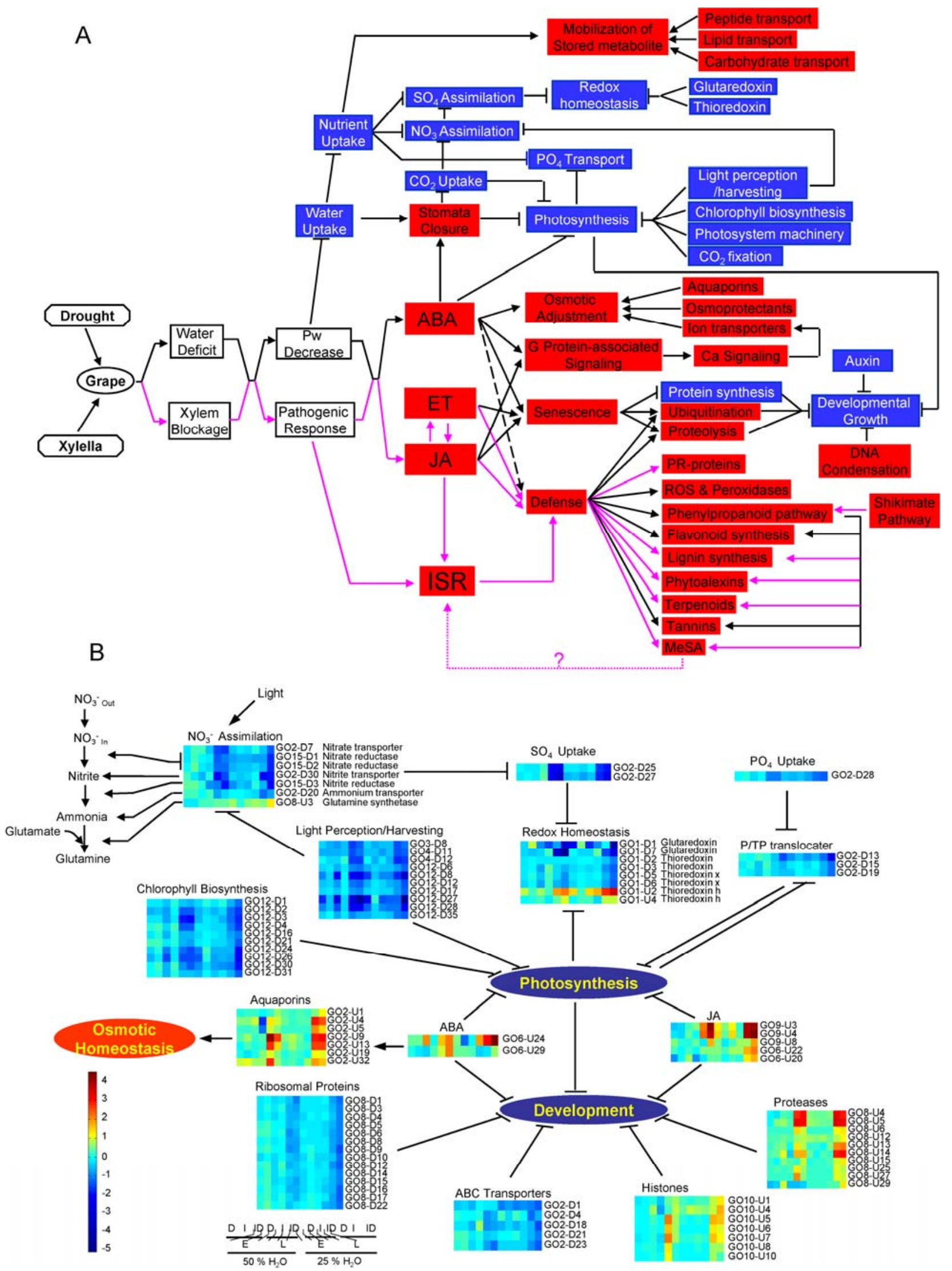

Fig. 8. Proposed physiological and transcriptional interaction network operating in response to Xylella infection and water deficit. A, Broad overview of pathways impacted by Xylella fastidiosa infection or water deficit. Upregulated responses are denoted with a red box and downregulated responses with a blue box. Inferred pathogen-regulated responses are highlighted with purple lines while physiological responses shared between $X$. fastidiosa infection and drought stress are denoted with black lines. Positive interactions are denoted by arrows and negative interactions by perpendicular terminal lines. ABA, abscisic acid; JA, jasmonic acid; MeSA, methylsalicylate; ET, ethylene; Pw, water potential; ISR, induced systemic resistance; PR, pathogenesis-related; ROS, reactive oxygen species. B, Summary of transcriptional responses related to plastid function, photosynthesis, and development. 
thus, may mediate responses within the xylem. Here, we observed an increase in transcripts in xylem-associated cells, particularly in the region of protoxylem (Fig. 7). We speculate host molecules (e.g., cell wall oligomers) released through the action of pathogen-secreted enzymes. Consistent with this speculation, we observed an LRR kinase homolog induced in protoxylem tissue (Fig. 7P compared with Q). In tomato the I-2 nucleotide-binding LRR disease resistance gene is expressed in xylem-associated parenchyma cells (Mes et al. 2000) and detects the presence of the secreted-in-xylem-3 protein, an effector protein that is secreted into xylem sap by the pathogen Fusarium oxysporum (Takken and Rep 2010). Thus, living cells in contact with xylem tissue may mediate defense responses to xylem-localized pathogens. Regardless of the origin of the response, the observed defense transcripts are insufficient to prevent development of disease, perhaps due to inadequate speed of induction, insufficient magnitude, or ineffective localization.

A great deal of recent research has explored the function of plant hormones as modulators of abiotic and biotic stress (Robert-Seilaniantz et al. 2011), and many of these studies reveal upregulation of hormone biosynthesis as an important site of regulation. In addition to the early and strong induction of a key enzyme in ABA biosynthesis, mentioned above, we also observed the upregulation of two allene oxide synthase paralogs and three lipoxygenase paralogs, consistent with the activation of jasmonic acid (JA) synthesis (Gfeller et al. 2010), as is the activation of a methyltransferase (GO17-U10) implicated in conversion of JA to MeJA. GO17-U10 is equally similar to two Arabidopsis genes, one involved in MeJA (At1g19640) and the other in MeSA (At3g11480) synthesis (Chen et al. 2003; Seo et al. 2001); however, the absence of upregulated transcripts involved in SA biosynthesis is most consistent with a role for GO17-U10 in MeJA production. We also observed induction of an entire set of enzymes involved in the S-adenosyl methionine cycle, which, among other activities, provides methyl groups for production of volatile MeJA as well as $\mathrm{MeSA}$, and also services a variety of methyl transferases involved in lignin biosynthesis.

There is considerable evidence of ABA as a negative regulator of disease resistance; thus, it is conceivable that water-stressinduced $\mathrm{ABA}$ is a primary factor predisposing $V$. vinifera to Pierce's disease. In Arabidopsis, drought-induced increases to ABA were associated with decreased resistance to Pseudomonas syringae pv. tomato (Mohr and Cahill 2003, 2007) and ABA was shown to interfere with JA-ethylene (ET) signaling, thereby increasing susceptibility to F. oxysporum (Anderson et al. 2004). Moreover, Fan and associates (2009) observed that increased transcription of Arabidopsis NCED5 by activation tagging led to increased levels of $\mathrm{ABA}$ and decreased resistance to $P$. syringae and several biotrophic fungal pathogens.

Although there is substantial complexity and nuance and some uncertainty regarding the precise relationships between classical plant hormones and disease, it is clear that interactions among plant hormone signaling pathways can be determinative to disease development and that the outcome (i.e., susceptibility or resistance) is often reflective of pathogen lifestyle, differing between biotrophic, hemibiotrophic, and necrotrophic interactions (Robert-Seilaniantz et al. 2011). Key convergence points between biotic and abiotic response networks have been suggested to include redox homeostasis (Davletova et al. 2005; Laloi et al. 2004), $\mathrm{Ca}^{2+} / \mathrm{CDPK}$-signaling (Chung et al. 2004; Ludwig et al. 2004, 2005), F-box mediated protein degradation (Hou et al. 2010; Navarro et al. 2008), mitogenactivated protein kinase cascades (Jonak et al. 2002; Nakagami et al. 2005; Rasmussen et al. 2012), and transcriptional regulators (e.g., AtMYC2 and AtMYB2 [Abe et al. 2003] and RD26/NAC TF [Fujita et al. 2004]). The current data provide that such living tissue at the xylem periphery could sense and respond to molecular components of the Xylella pathogen (pathogen- or mitogen-associated molecular patterns) or to evidence for transcriptional modification of many genes related to these activities.

Despite the presumably adaptive role for transcription related to defense and drought stress, the ultimate result of Xylella infection in grape is physiological dysfunction and disease. To gain insight into the potential impact of disease and drought stress on host metabolism, we organized transcripts according to inferred biochemical pathways using a combination of literature review and the MapMan software package (Thimm et al. 2004; Usadel et al. 2005). We observed coupled expression of sucrose synthase and invertase, suggesting physiological readjustment of leaves from a source of fixed carbon in healthy plants to a sink organ when challenged by $X$. fastidiosa or water deficit. This interpretation is further supported by our incidental observation of subcellular structures that resemble starch granules in the petioles of healthy but not diseased leaves (Choi et al. 2010). These transcriptional and cellular changes are consistent with the model described by Seo and associates (2007), in which source-to-sink transition in a timely manner is crucial for a successful defense against pathogen attack.

The strong downregulation of a number of functionally related transcripts suggests reductions to uptake and assimilation of inorganic nutrients, photosynthesis, plant growth and development, and cellular homeostasis (Fig. 8). Many but not all of these activities are related to plastid function. For example, transcription data reveal repression of a series of genes involved in nitrate assimilation and transport, as well as the uptake and translocation of inorganic sulfate and phosphate. Similarly, 35 genes involved in photosynthesis, including 7 chlorophyll $\mathrm{a} / \mathrm{b}$ binding proteins and numerous genes involved in chlorophyll biosynthesis, were strongly downregulated. Decreased abundance of photosynthesis-related transcripts is one characteristic of stress-mediated decay, which is a well-characterized post-transcriptional mechanism that reduces the abundance of specific transcripts in response to abiotic stress, especially those involved in photosynthesis (Park et al. 2012). In addition to a reduction in plastid-related functions, retardation of normal growth and development is suggested by the upregulation of large sets of proteases and histones and downregulation of numerous transcripts coding for proteins involved in protein biosynthesis (14 ribosomal proteins identified) and ABC transporters.

\section{A model for the development of Pierce's disease of grape.}

Disruption of xylem functionality resulting from bacterial colonization or plant-derived tyloses and pectin gels has been proposed to be the main mechanism driving the development of Pierce's disease symptoms (Hopkins 1989; Perez-Donoso et al. 2007; Stevenson et al. 2004). Indeed, low leaf water potential $\left(\psi_{1}\right)$ and turgor, impaired stem hydraulic conductance, and reduced $g_{\mathrm{s}}$ have all been associated with water-stressed (Williams and Matthews 1990) and Xylella-infected grapevines (Goodwin et al. 1988). Here, we have shown that the presence of the pathogen alone induced a more negative $\psi_{\mathrm{pd}}$ than did deficit irrigation, suggesting that water stress imposed by the pathogen can be locally more severe than that imposed by low water availability in the soil. Because $\psi_{\mathrm{pd}}$ is normally considered to be in equilibrium with the soil's water potential (Correia et al. 1995; Winkel and Rambal 1993) under well-watered conditions, reduction in $\psi_{\mathrm{pd}}$ suggests impaired capacity of infected vines to mobilize water through the soil-plant-atmosphere continuum. Moreover, the combined impact of low soil water content and cavitated or occluded vessels that cannot be refilled during the night period 
(Tyree and Zimmermann 2002) could synergistically decrease $\psi_{\mathrm{pd}}$ and, thereby, impact a range of interconnected parameters in a similarly synergistic manner.

We propose that such a dynamic is established during Pierce's disease, leading initially to pathogen-imposed drought stress and to activation of an ABA-regulated drought stress response in asymptomatic leaves. In addition to regulating the induction of stress-response genes, ABA is a key regulator of leaf senescence (Lee et al. 2001) and stomatal closure (Wilkinson and Davies 2002); thus, high levels of ABA could trigger the observed dysfunction of physiological networks. ABA is known to increase dramatically in xylem in response to water deficit (Correia et al. 1995) which, combined with its known antagonistic effect on host defense responses (RobertSeilaniantz et al. 2011), could preclude a timely, effective defense response to Xylella infection. Such a situation would favor increased bacterial spread and growth within xylem vessels, a further reduction to xylem conductivity, and renewed increases to ABA with its attendant consequences. Baccari and Lindow (2011) proposed that leaf scorch disease develops from failed homeostasis in the bacterium's density-dependent regulatory circuit, which normally prevents the buildup of large numbers of bacterial cells within individual xylem vessels. Here, we add to this model by suggesting that the resulting reductions to xylem conductivity induce ABA-related processes that, while attempting to maintain osmotic balance, serve to further exacerbate disease development. Ultimately, host defenses are induced but these are apparently too little or too late. We suggest that this scenario reflects a commensalistic relationship gone badly.

\section{MATERIALS AND METHODS}

\section{Plant materials, bacterial culture, and stress treatments.}

Two-year-old vines ( $V$. vinifera L. 'Cabernet Sauvignon' clone 8 on 'Freedom' rootstock) were grown for 1 year under greenhouse conditions in 10-in. pots containing 50\% Turface fritted clay by volume (Profile Products LLC, Buffalo Grove, IL, U.S.A.) and 50\% Pro-Mix BX peat moss (Premier Tech Ltd., Quebec, Canada) amended with $0.2 \mathrm{~kg}$ per vine of 18-612 Multicote fertilizer (N-P-K; Schultz Co., Bridgeton, MO, U.S.A.). Prior to bud break, plants were moved to growth chambers with a light and dark periods of 14 and $10 \mathrm{~h}$, respectively, at a photosynthetic photon flux density intensity of approximately $1,000 \mathrm{mmol}$ photons $\mathrm{m}^{-2} \mathrm{~s}^{-2}$; a daily air temperature regime of 25 and $20^{\circ} \mathrm{C}$, day and night, respectively; and 50 and $80 \%$ relative humidity for the photo- and nictoperiod, respectively. Plants were organized in a block design of three rows, with all treatments randomized in each row. Subsequent to a 4-week acclimation period, grapevines were pruned to produce a uniform shoot architecture consisting of two shoots per plant and 10 leaves per shoot. Approximately 2 weeks after full bloom, the shoot apical meristems were removed to prevent further growth. Laterals were removed throughout the season to contain growth and ensure a uniform light environment.

Vines were watered on a daily basis with nutrient solution (GrowMore 4-18-38 at $0.11 \mathrm{~g} /$ liter, boron removed) using pressure-compensated drip emitters, with watering rates depending on imposed treatment. Daily water uptake was calculated using a mini-lysimeter on plants watered to field capacity. The resulting $100 \%$ water usage was used to establish subsequent watering rates: $100 \%$ (water sufficient), $50 \%$ (moderate stress), and 25\% (severe stress). Two different growth chambers were used to house the two different irrigation level experiments: a moderate water deficit chamber, with vines irrigated at $50 \%$ of estimated daily vine water use, and a severe water deficit chamber, with vines irrigated at $25 \%$ of estimated daily vine water use. Four different treatments were imposed in each chamber: i) a mock-inoculated control, in which vines were inoculated with deionized water and irrigated at $100 \%$ of estimated daily vine water use; ii) a Xylellainoculated treatment, with vines irrigated at $100 \%$ of estimated daily vine water use, iii) a water-deficit treatment, with vines irrigated at either 25 or $50 \%$ full daily water use; and iv) vines doubly treated by Xylella inoculation and water deficit. Four biological replicates were performed in each chamber and plants were sampled at two time points, as described below. In total, 64 samples were processed for microarray analyses and, allowing for attrition, all expression values were derived from a minimum of three biological replicates.

$X$. fastidiosa Fetzer was grown at $28^{\circ} \mathrm{C}$ on PD3 agar medium for 2 weeks (Davis et al. 1981), at which point bacterial cells were harvested into $2 \mathrm{ml}$ of sterile water and adjusted to an optical density at $600 \mathrm{~nm}$ of $0.25\left(10^{8}\right.$ cells $\left./ \mathrm{ml}\right)$. Bacterial suspension $(5 \mu \mathrm{l})$ was placed in triplicate on the basal internode of each shoot and a 27-gauge hypodermic needle was pushed through the inoculum droplet into the stem to facilitate uptake into the vascular system.

Four weeks after the initiation of treatment, the third and fourth leaves were harvested from three plants of each treatment type and used for pre-symptomatic transcriptional analysis. At 8 weeks following the treatments, when symptoms were evident on infected individuals, the fifth and sixth leaves from the same grapevines were harvested for the post-symptomatic transcriptional analysis.

\section{Physiological measurements.}

Gas exchange was measured using an LI-6400 portable infrared gas exchange analyzer configured with a red/blue light source (Li-Cor Biosciences Inc., Lincoln, NE, U.S.A.). Only well-exposed, fully expanded mature leaves on the upper part of the main shoot were used for gas exchange and vine water status measurements. All gas-exchange measurements were conducted at saturating light $\left(1,500 \mathrm{mmol}\right.$ photons $\left.\mathrm{m}^{-2} \mathrm{~s}^{-1}\right)$ and reference $\mathrm{CO}_{2}\left(\mathrm{CO}_{2}\right.$ at $\left.1,500 \mathrm{ppm}\right)$ conditions. Under these conditions, net assimilation rates $\left(A_{n}\right)$ correspond to the maximum carboxylation potential of the leaf in the absence of stomatal limitations $\left(A_{n, \max }\right)$. Leaf temperature and relative humidity within the leaf chamber were set at $25^{\circ} \mathrm{C}$ and $50 \%$, respectively, to be consistent with growth chamber conditions.

Pre-dawn leaf water potential was measured using the pressure chamber method (Scholander et al. 1965) approximately 2 $\mathrm{h}$ after lights were turned off in the growth chamber in order to let plants equilibrate with soil moisture. Selected leaves were pressurized with an SME 3000 pressure chamber (Soil Moisture Equipment Inc., Santa Barbara, CA, U.S.A.) as described previously (Williams and Araujo 2002).

Carbon isotope discrimination analysis was conducted on replicate samples on the same leaves used for RNA extraction. Approximately $20 \mathrm{mg}$ of air-dried ground leaf material was placed in aluminum tins and submitted for analysis at the Stable Isotope Facility, University of California, Davis.

Data were analyzed using analysis of variance and Tukey's test for multiple means comparison using a least significant difference set at $P=0.1$. Statistical analysis and graphics were conducted in the statistical package SAS (version 9.1.3; SAS Institute Inc., Cary, NC, U.S.A.), SigmaPlot (version 8.02a; Systat Software Inc., Chicago), Matlab (version 7; The MathWorks, Inc., Natick, MA, U.S.A.), and Excel (Microsoft Inc., Seattle, WA, U.S.A.).

RNA isolation and microarray analysis.

Total RNA was isolated as described by Iandolino and associates (2004). Total RNA (4 $\mu \mathrm{g}$ ) was used to make biotin- 
labeled cRNA targets using the One-Cycle cDNA Synthesis Kit (Affymetrix, Santa Clara, CA, U.S.A.) followed by cDNA cleanup, biotin labeling, and fragmentation according to the manufacturer's instructions. The Affymetrix GeneChip Vitis vinifera Genome Array, which represents approximately 14,470 Vitis transcripts, was used. Hybridization, staining, and scanning were conducted using standard Affymetrix protocols, with the aid of the microarray facility in the University of CaliforniaDavis Genome Center. Microarray data were collected from scanned GeneChip images and analyzed using GCOS 1.2 (Affymetrix), Dchip (Li and Wong 2001), and R package. Normalized and statistically processed microarray data were exported into Microsoft Excel and used for GO-based functional classification and clustered data display using MatLab software (The MathWorks, Inc.).

\section{Microarray data statistical analysis.}

Probe signal intensities in *.DAT files were processed with the Affymetrix GCOS software package (version 1.2). Resulting *.CEL files were imported into the Bioconductor software suite (Gentleman et al. 2004) in R (Ihaka and Gentleman 1996) for data quality control. Files were then analyzed using the AffylmGUI package procedure for time course experiments as described by Smyth (2005). The GC Robust Multichip Analysis (Wu et al. 2004) in AffylmGUI was used for background adjustment, cross-chip quantile normalization, and median polish summarization of probe-level expression data. Differentially expressed genes were identified using a moderated $t$ test with Benjamini-Hochberg adjustment for false discovery rate (Smyth 2004). A standard linear model of the expression data for Limma was created within AffylmGUI, expressed as $I_{i j k m}=\mathrm{m}+a_{i}+T_{j}+t_{k}+t T_{i j}+r_{i j k m}$, where $I$ corresponds to probe-set intensity, $a$ to array, $T$ to treatment, $t$ to time, and $r$ to the residual. Subindexes correspond to $i$, arrays; $j$, treatments; $t$, time; and $m$, oligos. All possible contrasts within an irrigation treatment were calculated to identify differentially expressed genes. Two different sets of cut-offs were set to identify two distinct sets of differentially expressed genes. Genes in the first group have a $\log 2$ ratio (M) greater than or equal to 1 and a $p$ adjusted by false discovery rate $(\mathrm{P})$ smaller than or equal to 0.05 . Genes passing the more stringent cut-offs of the second group have an $\mathrm{M}$ smaller than 1 and a $\mathrm{P}$ value smaller or equal to 0.01 . Genes in both groups had an empirical Bayes log odds of differential expression (B) greater than or equal to 0 .

Finally, a core set of differentially expressed genes was created by pulling together genes that were identified as differentially expressed in at least one of the performed contrasts. This final core set was used for subsequent expression analysis and interpretation.

Raw data of the transcript profiles can be found in the Gene Expression Omnibus with the accession code GSE44213.

Functional classification and biochemical pathway analysis.

GO biological process classifications for each gene were determined using GO terms at The J. Craig Venter Institute or from the international GO project (Gene Ontology Consortium 2006). Biochemical gene networks were constructed using a combination of tools, including literature review of established pathways, cross-reference to the Kyoto Encyclopedia of Genes and Genomes (Kanehisa et al. 2004), and MapMan pathway analysis software (Thimm et al. 2004; Usadel et al. 2005).

\section{Real-time RT-PCR.}

PCR primers and probes were designed using Primer Express (ver1.5a; Applied Biosystems, Forster City, CA, U.S.A.). Twenty-two grapevine transcripts selected from microarray analysis, including actin as a control, were used as template sequences for primer and probe design. Primer and probe sequences for $X$. fastidiosa $16 \mathrm{~S}$ rDNA (Xf16S) were used as the molecular indicator of Xylella infection. TaqMan probes were developed as described by Schaad and associates (2002) and adopted to detect RNA instead of DNA. Two different $5^{\prime}$ fluorescent reporter dyes were used: 6-carboxyfluorescein, $\lambda_{\mathrm{em}}=$ 518 , for the grape genes and 6-carboxy-4,7,2',7'-tetrachlorofluorescein, $\lambda_{\mathrm{em}}=540$, for Xf16S. An appropriate Black Hole Quencher was coupled as the quencher dye. Both primers and probes were synthesized by Sigma-Genosys (The Woodlands, TX, U.S.A.).

First-strand cDNA was synthesized using Omniscript Reverse Transcriptase kit (Qiagen, Valencia, CA, U.S.A.) according to the manufacturer's instructions. The reaction mixture was incubated for $1 \mathrm{~h}$ at $37^{\circ} \mathrm{C}$ in a Tetrad thermocycler (MJ Research, San Francisco) prior to real-time PCR using an iCycler iQ Real-Time Detection System (Bio-Rad Laboratories, Hercules, CA, U.S.A.). PCR thermocycling reactions consisted of a 15-min initial denaturation and activation step; followed by 40 cycles at $94^{\circ} \mathrm{C}$ for $20 \mathrm{~s}, 59^{\circ} \mathrm{C}$ for $20 \mathrm{~s}$, and $72^{\circ} \mathrm{C}$ for $20 \mathrm{~s}$; with a final extension step of 5 min at $72^{\circ} \mathrm{C}$.

\section{In situ localization.}

Petioles were collected from Cabernet Sauvignon plants, clone 8, inoculated with the Fetzer strain of $X$. fastidiosa or mock-inoculated with sterile water at 3 and 4 months after inoculation. Petiole tissues were fixed in $1.85 \%$ formaldehyde, $5 \%$ glacial acetic acid, and $63 \%$ ethanol; dehydrated through an ethanol series (70, 80, 90, and 100\%, 30 min each); embedded in paraffin; and sectioned using a Microtome HM $340 \mathrm{E}$ (MICROM International, Walldorf, Germany). Specimens were stained with $0.1 \%$ toluidine blue O. In situ hybridizations were performed as previously described (Long et al. 1996). DNA fragments for probe production were obtained by means of PCR amplification from corresponding cDNA clones from a grape expressed sequence tag [spelled "EST"] library (Goes da Silva et al. 2005) and used as a DNA template to make an RNA antisense probe by T7 RNA polymerase. Samples were visualized with a Nikon Eclipse E600 light microscope (Nikon, Tokyo) equipped with an RT Color Spot (Diagnostic Instruments, Inc., Sterling Heights, MI, U.S.A.) digital camera. Images were acquired using SPOT image program (version 3.5; Diagnostic Instruments Inc.).

\section{ACKNOWLEDGMENTS}

Financial support from the California Department of Food and Agriculture (CDFA 02-0150) is gratefully acknowledged. This research was also supported by a grant from the Next-Generation BioGreen 21 Program (PJ008124, PJ009089), Rural Development Administration, and Basic Science Research Program through the National Research Foundation of Korea (NRF) funded by the Ministry of Education, Science and Technology (number 0007817), Republic of Korea.

\section{LITERATURE CITED}

Abe, H., Urao, T., Ito, T., Seki, M., Shinozaki, K., and YamaguchiShinozaki, K. 2003. Arabidopsis AtMYC2 (bHLH) and AtMYB2 (MYB) function as transcriptional activators in abscisic acid signaling. Plant Cell 15:63-78.

Anderson, J. P., Badruzsaufari, E., Schenk, P. M., Manners, J. M., Desmond, O. J., Ehlert, C., Maclean, D. J., Ebert, P. R., and Kazan, K. 2004. Antagonistic interaction between abscisic acid and jasmonate-ethylene signaling pathways modulates defense gene expression and disease resistance in Arabidopsis. Plant Cell 16:3460-3479.

Attaran, E., Zeier, T. E., Griebel, T., and Zeier, J. 2009. Methyl salicylate production and jasmonate signaling are not essential for systemic acquired resistance in Arabidopsis. Plant Cell 21:954-971.

Baccari, C., and Lindow, S. E. 2011. Assessment of the process of move- 
ment of Xylella fastidiosa within susceptible and resistant grape cultivars. Phytopathology 101:77-84.

Boller, T., and He, S. Y. 2009. Innate immunity in plants: An arms race between pattern recognition receptors in plants and effectors in microbial pathogens. Science 324:742-744.

Bonetta, D., and McCourt, P. 1998. Genetic analysis of ABA signal transduction pathways. Trends Plant Sci. 3:231-235.

Borovskii, G. B., Stupnikova, I. V., Antipina, A. I., Vladimirova, S. V., and Voinikov, V. K. 2002. Accumulation of dehydrin-like proteins in the mitochondria of cereals in response to cold, freezing, drought and ABA treatment. BMC Plant Biol. 2:5. doi:10.1186/1471-2229-2-5. Published online.

Casterrlarin, S. D., Pfeiffer, A., Silivotti, P., Degan, M., Peterlunger, E., and Di Gaspero, G. 2007. Transcriptional regulation of anthocyanin biosynthesis in ripening fruits of grapevine under seasonal water deficit. Plant, Cell Environ. 30:1381-1399.

Chatterjee, S., Almeida, R. P. P, and Lindow, S. E. 2008a. Living in two worlds: The plant and insect lifestyles of Xylella fastidiosa. Annu. Rev. Phytopathology 46:243-271.

Chatterjee, S., Wistrom, C., and Lindow, S. E. 2008b. A cell-cell signaling sensor is required for virulence and insect transmission of Xylella fastidiosa. Proc. Natl. Acad. Sci. U.S.A. 105:2670-2675.

Chen, F., Auria, J. C., Tholl, D., Ross, J. R., Gershenzon, J., Noel, J. P., and Pichersky, E. 2003. An Arabidopsis thaliana gene for methylsalicylate biosynthesis, identified by a biochemical genomics approach, has a role in defense. Plant J. 36:577-588.

Choi, H.-K., Goes da Silva, F., Lim, H.-J., Iandolino, A., Seo, Y.-S., Lee, S.-W., and Cook, D. R. 2010. Diagnosis of Pierce's disease using biomarkers specific to Xylella fastidiosa rRNA and Vitis vinifera gene expression. Phytopathology 100:1089-1099.

Chung, E., Park, J. M., Oh, S.-K., Joung, Y. H., Lee, S., and Choi, D. 2004 Molecular and biochemical characterization of the Capsicul annuum calcium-dependent protein kinase $3(\mathrm{CaCDPK} 3)$ gene induced by abiotic and biotic stresses. Planta 220:286-295.

Correia, M. J., Pereira, J. S., Chaves, M. M., Rodriguez, M. L., and Pacheco, C. A. 1995. ABA xylem concentrations determine maximum daily leaf conductance of field-grown Vitis vinifera L. plants. Plant Cell Environ. 18:511-521.

Cramer, G. R., Ergul, A., Grimplet, J., Tillett, R. L., Tattersall, E. A. R., Bohlman, M. C., Vincent, D., Sonderegger, J., Evans, J., Oxborne, C., Quilici, D., Schlauch, K. A., Schooley, D. A., and Cushman, J. C. 2007. Water and salinity stress in grapevinew: Early and late changes in transcript and metabolite profiles. Funct. Integr. Genomics 7:111-134.

Davis, M. J., French, W. J., and Schaad, N. W. 1981. Axenic culture of the bacteria associated with phony disease of peach and plum leaf scald. Curr. Microbiol. 6:309-314.

Davletova, S., Rizhsky, L., Liang, H., Shengqiang, Z., Oliver, D. J., Coutu, J., Shulaev, V., Schlauch, K., and Mittler, R. 2005. CYTOSOLIC ASCORBATE PEROXIDASE 1 is a central component of the reactive oxygen gene network of Arabidopsis. Plant Cell 17:268-281.

Fan, J., Hill, L., Crooks, C., Doerner, P., and Lamb, C. 2009. Abscisic acid has a key role in modulating diverse plant-pathogen interactions. Plant Physiol. 150:1750-61

Fujita, M., Fujita, Y., Maruyama, K., Seki, M., Hiratsu, K., Ohme-Takagi, M., Tran, L. S., Yamaguchi-Shinozaki, K., and Shinozaki, K., 2004. A dehydration-induced NAC protein, RD26, is involved in a novel ABAdependent stress-signaling pathway. Plant J. 39:863-876.

Gene Ontology Consortium. 2006. The Gene Ontology (GO) project in 2006. Nucleic Acids Res. 34:D322-D326.

Gentleman, R. C., Carey, V. J., Bates, D. M., Bolstad, B., Dettling, M., Dudoit, S., Ellis, B., Gautier, L., Ge, Y., Gentry, J., Hornik, K., Hothorn, T., Huber, W., Iacus, S., Irizarry, R., Leisch, F., Li, C., Maechler, M., Rossini, A. J., Sawitzki, G., Smith, C., Smyth, G., Tierney, L., Yang, J. Y., and Zhang, J. 2004. Bioconductor: Open software development for computational biology and bioinformatics. Genome Biol. 5:R80. Published online.

Gfeller, A., Dubugnon, L., Liechti, R., and Farmer, E. E. 2010. Jasmonate biochemical pathway. Sci. Signal. 3:cm3. doi:10.1126/scisignal.3109cm3. Online publication.

Goes da Silva, F., Iandolino, A., Al-Kayal, F., Bohlmann, M. C., Cushman, M. A., Lim, H., Figueroa, R., Leslie, A., Xu, J., Kabuloglu, E. K., Tattersall, E., Ergul, A., Baek, J. M., Cramer, G. R., Cushman, J. C., and Cook, D. R. 2005. Characterizing the grape transcriptome. Analysis of expressed sequence tags from multiple Vitis species and development of a compendium of expression during berry development. Plant Physiol. 139:574-597.

Goodwin, P. H., DeVay, J. E., and Meredith, C. P. 1988. Roles of water stress and phytotoxins in the development of Pierce's disease of the grapevine. Physiol. Mol. Plant Pathol. 32:1-15.

Hopkins, D. L. 1989. Xylella fastidiosa: Xylem-limited bacterial pathogen of plants. Annu. Rev. Phytopathol. 27:271-290.

Hose, E., Steudle, E., and Hartung, W. 2000. Abscisic acid and hydraulic conductivity of maize roots: A study using cell- and root-pressure probes. Planta 211:874-882.

Hou, X., Lee, L. Y., Xia, K., Yan, Y., and Yu, H. 2010. DELLAs modulate jasmonate signaling via competitive binding to JAZs. Dev. Cell 14:884894.

Iandolino, A. B., Goes da Silva, F., Lim, H., Choi H.-K., Williams, L. E., and Cook, D. R. 2004. High-quality RNA, cDNA and derived EST libraries from grapevine (Vitis vinifera L.). Plant Mol. Biol. Rep. 22:269-278.

Ihaka, R., and Gentleman, R. 1996. R: A language for data analysis and graphics. J. Comput. Graph. Stat. 5:299-314.

Iuchi, S., Kobayashi, M., Yamaguchi-Shinozaki, K., and Shinozaki, K. 2000. A stress-inducible gene for 9-cis-epoxycarotenoid dioxygenase involved in abscisic acid biosynthesis under water stress in droughttolerant cowpea. Plant Physiol. 123:553-562.

Jonak, C., Okresz, L., Bogre, L., and Hirt, H. 2002. Complexity, cross talk and integration of plant MAP kinase signaling. Curr. Opin. Plant Biol. 5:415-424.

Kanehisa, M., Goto, S., Kawashima, S., Okuno, Y., and Hattori, M. 2004 The KEGG resource for deciphering the genome. Nucleic Acids Res. 32:277-280.

Kobayashi, Y., Yamamoto, S., Minami, H., Kagaya, Y., and Hattori, T. 2004. Differential activation of the rice sucrose nonfermenting1-related protein kinase 2 family by hyprosmotic stress and abscisic acid. Plant Cell 16:1163-1177.

Laloi, C., Apel, K., and Danon, A. 2004. Reactive oxygen signaling: The latest news. Curr. Opin. Plant Biol. 7:323-328.

Lee, I. C., Hong, S. W., Whang, S. S., Lim, P. O., Nam, H. G., and Koo, J. C. 2001. Age-dependent action of an ABA-inducible receptor kinase, $\mathrm{RPK} 1$, as a positive regulator of senescence in Arabidopsis leaves. Plant Cell Physiol. 53:651-662.

Li, C., and Wong, W. H. 2001. Model-based analysis of oligonucleotide arrays: Expression index computation and outlier detection. Proc. Natl. Acad. Sci. U.S.A. 98:31-36.

Liu, P. P., Yang, Y., Pichersky, E., and Klessig, D. F. 2010. Altering expression of benzoic acid/salicylic acid carboxyl methyltransferase $1 \mathrm{com}$ promises systemic acquired resistance and PAMP-triggered immunity in Arabidopsis. Mol. Plant-Microbe Interact. 23:82-90.

Long, J. A., Moan, E. I., Medford, J. I., and Barton, M. K. 1996. A member of the KNOTTED class of homeodomain proteins encoded by the STM gene of Arabidopsis. Nature 379 66-69.

Ludwig, A. A., Romeis, T., and Jones, J. D. G. 2004. CDPK-mediated signaling pathway: Specificity and cross-talk. J. Exp. Bot. 55:181-188.

Ludwig, A. A., Saitoh, H., Felix, G., Freymark, G., Miersch, O., Wasternack, C., Boller, T., Jones, J. D., and Romeis, T. 2005. Ethylene-mediated crosstalk between calcium-dependent protein kinase and MAPK signaling controls stress responses in plants. Proc. Natl. Acad. Sci. U.S.A. 102, 10736-10741.

Matthews, M. A., Ishii, R., Anderson, M. M., and O’Mahony, M. 1990. Dependence of wine sensory attributes on vine water status. J. Sci. Food Agric. 51:321-335.

Mes, J. J., van Doom, A. A., Wijbrandi, J., Simons, G., Comelissen, B. J. C., and Haring, M. A. 2000. Expression of the Fusarium resistance gene l-2 localizes with the site of fungal containment. Plant J. 23:183-193.

Mohr, P. G., and Cahill, D. M. 2003. Abscisic acid influences the susceptibility of Arabidopsis thaliana to Pseudomonas syringae pv. tomato and Peronospora parasitica. Funct. Plant Biol. 30:461-469.

Mohr, P. G., and Cahill, D. M. 2007. Suppression by ABA of salicylic acid and lignin accumulation and the expression of multiple genes, in Arabidopsis infected with Pseudomonas syringae pv. tomato. Funct. Integr. Genomics 7:181-191.

Nakagami, H., Pitzschke, A., and Hirt, H. 2005. Emerging MAP kinase pathways in plant stress signaling. Trends Plant Sci. 10:339-346.

Navarro, L., Bari, R., Achard, P., Lison, P., Nemri, A., Harberd, N. P., and Jones, J. D. 2008. DELLAs control plant immune responses by modulating the balance of jasmonic acid and salicylic acid signaling. Curr. Biol. 18:650-655

Newman, K. L., Almeida, R. P. P., Purcell, A. H., and Lindow, S. E. 2004 Cell-cell signaling controls Xylella fastidiosa interaction with both insects and plants. Proc. Natl. Acad. Sci. U.S.A. 101:1737-1742.

Nunney, L., Yuan, X., Bromley, R., Hartung, J., Montero-Astua, M. Moreira, L., Ortiz, B., and Stouthamer, R. 2010. Population genomic analysis of a bacterial plant pathogen: Novel insight into the origin of Pierce's disease of grapevine in the US. PLos One 5:e15488. doi:10.1371/journal.pone.0015488. Published online.

Nussbaum, J. C., and Locksley, R. M. 2012. Infectious (non)tolerancefrustrated commensalism gone awry? Cold Spring Harb. Perspect. Biol. $4: 1-13$ 
Park, S.-H., Chung, P., Juntawong, P., Bailey-Serres, J., Kim, Y., Jung, H., Bang, S., Kim, Y.-K., Choi, Y., and Kim, J. K. 2012. Posttranscriptional control of photosynthetic mRNA decay under stress conditions requires $3^{\prime}$ and $5^{\prime}$ untranslated regions and correlates with differential polysome association in rice. Plant Physiol. 159:1111-1124.

Perez-Alfocea, F., Ghanem, M. E., Gomez-Cadenas, A., and Dodd, I. C. 2011. Omics of root-to-shoot signaling under salt stress and water deficit. J. Integr. Biol. 15:893-901.

Perez-Donoso, A., Greve, L. C., Walton, J. H., Shackel, K. A., and Labavitch, J. M. 2007. Xylella fastidiosa infection and ethylene exposure result in xylem and water movement disruption in grapevine shoots. Plant Physiol. 143:1024-1036.

Purcell, A. H., and Hopkins, D. L. 1996. Fastidious xylem-limited bacterial plant pathogens. Annu. Rev. Phytopathol. 34:131-151.

Purcell, A. H., and Saunders, S. R. 1999. Fate of Pierce's disease strains of Xylella fastidiosa in common riparian plants in California. Plant Dis. 83:825-830.

Rasmussen, M. W., Roux, M., Petersen, M., and Mundy, J. 2012. MAP kinase cascades in Arabidopsis innate immunity. Front Plant Sci. 3:169. doi:10.3389/fpls.2012.00169. Published online.

Robert-Seilaniantz, A., Grant, M., and Jones, J. D. 2011. Hormone crosstalk in plant disease and defense: More than just salicylate/jasmonate antagonism. Annu. Rev. Phytopathol. 49:317-343.

Schaad, N. W., Opgenorth, D., and Gaush, P. 2002. Real-time polymerase reaction for one-hour on-site diagnosis of Pierce's disease of grape in early season asymptomatic vines. Techniques 92:721-728.

Scholander, P. F., Hammel, H. T., Bradstreet, E. D., and Hemmingsen, E. A. 1965. Sap pressure in vascular plants. Science 148:339-346.

Seo, H., Song J., Cheong, J.-J., Lee, Y.-H., Lee, Y.-W., Hwang, I., Lee, J., and Choi Y. 2001. Jasmonic acid carboxyl methyltransferase: A key enzyme for jasmonate-regulated plant response. Proc. Natl. Acad. Sci. U.S.A. 98:4788-4793.

Seo, Y., Cho, J., Lee, S., Ryu, H., Han, M., Hahn, T., Sonnewald, U., and Jeon, J. 2007. Current insight into the primary carbon metabolic flux that occurs in plants undergoing a defense response. Plant Stress 1:4249.

Shatil-Cohen, A., Attia, Z., and Moshelion, M. 2011. Bundle-sheath cell regulation of xylem-mesophyll water transport via aquaporins under drought stress: A target of xylem-borne ABA. Plant J. 67:72-80.

Sherald, J. L., and Kostka, S. L. 1992. Bacterial leaf scorch of landscape trees caused by Xylella fastidiosa. J. Arboricult. 18:57-63.

Simpson A. J., Reinach F. C., and Arruda, P. 2000. The genome sequence of the plant pathogen Xylella fastidiosa. Nature 406:151-157.

Smyth, G. K. 2004. Linear models and empirical Bayes methods for assessing differential expression in microarray experiments. Stat. Appl. Genet. Mol. Biol. 3:Article 3. Published online.

Smyth, G. K. 2005. Limma: Linear models for microarray data. Pages 397-420 in: Bioinformatics and Computational Biology Solutions using R and Bioconductor. R. Gentleman, V. Carey, S. Dudoit, R. Irizarry, and W. Huber, eds. Springer, New York.

Stevenson, J. F., Matthews, M. A., Greve, L. C., Labavitch, J. M., and
Rost, T. L. 2004. Grapevine susceptibility to Pierce's disease II: Progression of anatomical symptoms. Am. J. Enol. Viticult. 55:238-245.

Taji, T., Ohsumi, C., Luchi, S., Seki, M., Kasuga, M., Kobayashi, M. Yamaguchi-Shinozaki, K., and Shinozaki, K. 2002. Important role of drought- and cold-inducible genes for galactinol synthase in stress tolerance in Arabidopsis thaliana. Plant J. 29:417-426.

Takken, F., and Rep, M. 2010. The arms race between tomato and Fusarium oxysporum. Mol. Plant Pathol. 11:309-314.

Thimm, O., Blasing, O., Gibon, Y., Nagel, A., Meyer, S., Kruger, P., Selbig, J., Muller, L. A., Rhee, S. Y., and Stitt, M. 2004. MapMan: A user-driven tool to display genomics data sets onto diagrams of metabolic pathways and other biological processes. Plant J. 37:914-939.

Tyree, M. T., and Zimmermann, M. H. 2002. Xylem Structure and the Asceny of Sap, ed. 2. Springer, Berlin.

Usadel, B., Nagel, A., Thimm, O., Redestig, H., Blaesing, O. E., PalaciosRojas, N., Selbig, J., Hannemann, J., Piques, M. C., Steinhauser, D., Scheible, W. R., Gibon, Y., Morcuende, R., Weicht, D., Meyer, S., and Stitt, M. 2005. Extension of the visualization tool MapMan to allow statistical analysis of arrays, display of corresponding genes, and comparison with known responses. Plant Physiol. 138:1195-1204.

van der Schoot, C., and van Bel, A. J. E. 1989. Architecture of the intermodal xylem of tomato (Solanum lycopersicum) with reference to longitudinal and lateral transfer. Am. J. Bot. 76:487-503.

Varela, L. G., Smith, R. J., and Phillips, P. A. 2001. Pierce's disease. Publication 21600. University of California, Division of Agricultural and Natural Resource, Oakland, CA, U.S.A.

Wilkinson, S., and Davies, W. J. 2002. ABA-based chemical signaling: The co-ordination of response to stress in plants. Plant Cell Environ. 25:195-210.

Williams, L. E., and Araujo, F. J. 2002. Correlations among pre-dawn leaf, midday leaf, and midday stem water potential and their correlations with other measures of soil and plant water status in Vitis vinifera. J. Am. Soc. Hortic. Sci. 127:448-454.

Williams, L. E., and Matthews. M. A. 1990. Grapevine. Pages 1019-1055 in: Irrigation of Agricultural Crops. B. A. Stewart and D. R. Nielsen, eds. American Society of Agronomy, Madison, WI, U.S.A.

Winkel, T., and Rambal, S. 1993. Influence of water stress on grapevines growing in the field: From leaf to whole-plant response. Aust. J. Plant Physiol. 20:143-157.

Wu, Z., Irizarry, R. A., Gentleman, R., Martinez-Murillo, F., and Spencer, F. 2004. A model based background adjustment for oligonucleotide expression arrays. J. Am. Stat. Assoc. 99:909-917.

\section{AUTHOR-RECOMMENDED INTERNET RESOURCES}

Bioconductor software suite: www.bioconductor.org Gene Expression Omnibus database: www.ncbi.nlm.nih.gov/projects/geo The Gene Ontology website:www.geneontology.org J. Craig Venter Institute website: www.jcvi.org

R Project for Statistical Computing software: www.R-project.org 